\title{
Estrogen response element-dependent regulation of transcriptional activation of estrogen receptors $\alpha$ and $\beta$ by coactivators and corepressors
}

\author{
C M Klinge, S C Jernigan, K A Mattingly, K E Risinger and J Zhang \\ Department of Biochemistry and Molecular Biology, Center for Genetics and Molecular Medicine, University of Louisville School of Medicine, \\ Louisville, Kentucky 40292, USA \\ (Requests for offprints should be addressed to C M Klinge; Email: carolyn.klinge@louisville.edu)
}

\begin{abstract}
One mechanism by which ligand-activated estrogen receptors $\alpha$ and $\beta$ (ER $\alpha$ and $E R \beta$ ) stimulate gene transcription is through direct ER interaction with specific DNA sequences, estrogen response elements (EREs). ERE-bound ER recruits coactivators that stimulate gene transcription. Binding of ER to natural and synthetic EREs with different nucleotide sequences alters ER binding affinity, conformation, and transcriptional activity, indicating that the ERE sequence is an allosteric effector of ER action. Here we tested the hypothesis that alterations in ER conformation induced by binding to different ERE sequences modulates ER interaction with coactivators and corepressors. CHO-K1 cells transfected with ER $\alpha$ or ER $\beta$ show ERE sequence-dependent differences in the functional interaction of ER $\alpha$ and ER $\beta$ with coactivators steroid receptor coativator 1 (SRC-1), SRC-2 (glucocorticoid receptor interacting protein 1 (GRIP1)), SRC-3 amplified in breast cancer 1 (AIB1) and ACTR, cyclic AMP binding protein (CBP), and steroid receptor RNA activator (SRA), corepressors nuclear receptor co-repressor (NCoR) and silencing mediator for retinoid and thyroid hormone recpetors (SMRT), and secondary coactivators coactivator associated arginine methyltransferase 1 (CARM1) and protein arginine methyltransferase 1 (PRMT1). We note both ligand-independent as well estradiol- and 4-hydroxytamoxifen-dependent differences in ER-coregulator activity. In vitro ER-ERE binding assays using receptor interaction domains of these coregulators failed to recapitulate the cell-based results, substantiating the importance of the full-length proteins in regulating ER activity. These data demonstrated that the ERE sequence impacts estradioland 4-hydroxytamoxifen-occupied $\mathrm{ER} \alpha$ and $\mathrm{ER} \beta$ interaction with coregulators as measured by transcriptional activity in mammalian cells.
\end{abstract}

Journal of Molecular Endocrinology (2004) 33, 387-410

\section{Introduction}

Estrogens exert a wide variety of effects on growth, development, and differentiation primarily through binding to a specific intranuclear estrogen receptor protein (ER) encoded by two genes: $\alpha$ and $\beta$ (ER $\alpha$ and $\operatorname{ER} \beta$ ) (Couse \& Korach 1999). Stimulation of target gene expression in response to $17 \beta$-estradiol $\left(\mathrm{E}_{2}\right)$, or other agonists, is thought to be mediated by two mechanisms: (1) direct binding of $\mathrm{E}_{2}$-liganded ER $\left(\mathrm{E}_{2}-\mathrm{ER}\right)$ to a specific sequence called an estrogen response element (ERE) and (2) 'tethering', in which ER interacts with another DNAbound transcription factor, e.g. Spl (Safe 2001) or
AP-1 (Webb et al. 1995), in a way that stabilizes the DNA binding of that transcription factor in the absence of direct ER-DNA binding. Both processes result in recruitment of coactivators and components of the RNA polymerase II transcription initiation complex that enhances target gene transcription (Klinge 2000).

We recently reviewed studies on ER interaction with 38 estrogen-responsive genes whose promoters or 3' untranslated regions contain functional EREs (Klinge 2001). Most estrogen-regulated genes contain imperfect, non-palindromic EREs. One conclusion from our review is that the more nucleotide changes there are from the consensus 
within a half-site of the ERE palindrome, the lower the ER $\alpha$ binding affinity and the lower the transcriptional activity (Klinge 2001). Further, EREs in which nucleotides are altered in both arms of the palindrome show lower transcriptional activity than those containing alterations in only one ERE half-site (Klinge 2001). These results have been confirmed experimentally (Driscoll et al. 1998, Tyulmenkov \& Klinge 2000a, 2001a,b, Tyulmenkov et al. 2000, Kulakosky et al. 2002).

Lefstin \& Yamamoto (1998) proposed that response elements recognized by nuclear transcription factors, including members of the steroid/ nuclear receptor superfamily, contain information that is interpreted by bound regulator factors. Our data fit the model of Lefstin and Yamamoto by showing that different EREs bound $\operatorname{ER} \alpha$ with different affinity and resulted in different amounts of transactivation of a reporter plasmid in transfected cells (Tyulmenkov et al. 2000, Klinge et al. 2001, Tyulmenkov \& Klinge 2001b, Kulakosky et al. 2002). We and other investigators have proposed that DNA acts as an allosteric effector whose binding alters ER conformation such that different EREs would be hypothesized to regulate ER interaction with other proteins, e.g. coactivators or corepressors (reviewed in Klinge et al. 2001). In concordance with this hypothesis, we observed differences in $\mathrm{ER} \alpha$ conformation, assessed by $\alpha$-chymotrypsin or trypsin digestion, upon interaction with a palindromic ERE or nonpalindromic EREs from the human pS2, progesterone receptor $(\mathrm{PR})$, and $c$-fos genes and a direct repeat of the ERE half-site separated by $5 \mathrm{bp}$ (Klinge et al. 2001, Ramsey \& Klinge 2001). The ERE-mediated increase in $\mathrm{ER} \alpha$ sensitivity to protease digestion correlated with $\mathrm{E}_{2}$-stimulated transcription from the same EREs in transiently transfected cells and with the affinity of ER $\alpha$-ERE binding in vitro (Klinge et al. 2001, Ramsey \& Klinge 2001, Tyulmenkov \& Klinge 2001a,b, Kulakosky et al. 2002).

Similarly, other investigators have reported differential recognition of $\mathrm{ER} \alpha$ by select antibodies when $\mathrm{ER} \alpha$ was bound to the Xenopus laevis vitellogenin A2 (vit A2) ERE versus the nonpalindromic ERE from the human $\mathrm{pS} 2$ gene in electrophoretic mobility shift assay (EMSA) experiments (Wood et al. 1998). Limited protease digestion of $\mathrm{ER} \alpha$ bound to vit A2 ERE or the non-palindromic pS2, vitellogenin $\mathrm{B} 1$, and oxy- tocin EREs revealed different sized $\left[{ }^{32} \mathrm{P}\right] \mathrm{DNA}$ fragments in EMSAs (Wood et al. 2001). These data were interpreted as indicating that $\mathrm{ER} \alpha$ binding to different EREs changes ER $\alpha$ conformation (Wood et al. 1998, 2001). Likewise, experiments using phage display revealed conformational differences in $\mathrm{ER} \alpha$ and $\mathrm{ER} \beta$ when bound to vit $\mathrm{A} 2, \mathrm{pS} 2$, lactoferrin, and complement 3 (C3) EREs in vitro (Hall et al. 2002).

Only a few investigators have examined how these ERE-induced alterations in ER conformation impact ER-coactivator interaction. One study reported that GRIP1 showed less interaction when $\mathrm{ER} \alpha$ bound to the pS2 ERE versus the vit A2, vitellogenin $\mathrm{B} 1$, or oxytocin EREs, indicating that the ERE sequence impacts ER $\alpha$-GRIP1 interaction in vitro (Wood et al. 2001). Similar conclusions based on EMSA and GST-pulldown assays were recently reported by another group of investigators (Yi et al. 2002). However, the functional significance of these observations of ERE-dependent differences in ER conformation and recognition by coactivator receptor interaction domains (RIDs) has not been tested by cell-based transcription assays.

Over the past 6 years, at least 28 different $\mathrm{ER} \alpha$ coactivator proteins have been identified (McKenna et al. 1999, Klinge 2000, McKenna \& O'Malley 2002). Less information is available regarding ER $\beta$-coactivator interaction. In brief, coactivators function to (1) acetylate the N-terminal tails of lysine residues in histones $\mathrm{H} 3$ and $\mathrm{H} 4$ leading to 'relaxed' chromatin structure (reviewed in Struhl 1998), (2) acetylate other transcription factors and coactivators (Jiang et al. 2000), (3) recruit secondary coactivators including coactivator associated arginine methyltransferase 1 (CARM1) and protein arginine methyltransferase 1 (PRMT1) that methylate histones (Koh et al. 2001), (4) interact with components of various ATPdependent chromatin-remodeling complexes (Hebbar \& Archer 2003), and (5) direct interaction with and stabilization of basal transcription factor binding (reviewed in Hager et al. 1998). Once the transcription initiation complex is complete, RNA polymerase II is recruited to the transcription start site and begins transcription.

Most of the cell-based assays examining the effects of coactivators on ER-mediated transcription have used reporter genes containing two or three tandem copies of the vit A2 ERE (Norris et al. 1998, Lee et al. 1999, Mak et al. 1999, 
Delage-Mourroux et al. 2000). The nonpalindromic EREs that have been used in transfection experiments are from the complement $\mathrm{C} 3$, transforming growth factor- $\beta 3$, and lactoferrin gene promoters that were used to examine the functional interaction of $\mathrm{ER} \alpha$ with the receptor of estrogen receptor activity (Delage-Mourroux et al. 2000) and SRC-2/GRIP1 (Norris et al. 1998).

Selective estrogen receptor modulators (SERMS) in vitro and in transfected cells (Metivier et al. 2002). Treatment of cells with the histone deacetylase (HDAC) inhibitor trichostatin A has been shown to enhance ligand-independent as well as $\mathrm{E}_{2^{-}}$, tamoxifen-, and raloxifene-stimulated $\mathrm{ER} \alpha$ transcription of an ERE-reporter gene, indicating that repression of $\mathrm{ER} \alpha$ transcriptional activity is mediated by a corepressor-HDAC complex (Webb et al. 2003). To address the functional consequences of the ERE sequence-dependent alterations on $\mathrm{ER} \alpha$ - or $\mathrm{ER} \beta$-coactivator interaction, we have performed transient transfection experiments and quantitated the impact of representative coactivators on $\mathrm{E}_{2}$-induced reporter gene expression from single copies of the vit A2, pS2, PR, and c-fos EREs. We report that different ERE sequences alter coactivator enhancement of $\mathrm{E}_{2}$-induced transcriptional activity by $\mathrm{ER} \alpha$ and ER $\beta$. Further, differences in coactivator interaction between $\mathrm{ER} \alpha$ and ER $\beta$ were also apparent. These data demonstrated that alterations in ERE sequence functionally impact coregulatory protein interaction with $\mathrm{ER} \alpha$ and $\operatorname{ER} \beta$ and that $\mathrm{ER} \alpha$ and $\operatorname{ER} \beta$ show subtype-dependent coactivator interactions.

\section{Materials and methods}

\section{ER preparation and ER-ERE $\boldsymbol{K}_{\mathrm{d}}$ determinations}

Human ER $\alpha$ and $E R \beta 1$ were expressed from baculoviruses in Sf21 cells as described (Kulakosky et al. 2002). EMSAs were used to determine the affinity of $\mathrm{E}_{2}$-occupied $\mathrm{ER} \alpha$ and $\mathrm{ER} \beta$ for the following EREs: EREc13: 5'-CGGGTCAGAG TGACGAG-3'; EREc38 (which is identical to the commonly used Xenopus vit A2 ERE (Peale et al. 1989)): 5'-CGAGGTCAGAGTGACGTGAGCTA AAATAACACATT-3'; PR11 48: 5'-AGCGCTCG GTGCTGCGAGGTGACGAGGTCTTGGTGG CTGTTT-3'; pS2: 5'-CTTCGCGCTGGAAGG TCAGCGTGGCAACACGGTGAGCGACT-3'; and Fos-1211: 5'-AGCTTGGGCTGAGCCGG CAGCGTGACACGGCATG-3'.

The underlined nucleotides correspond to the minimal core consensus ERE. The nucleotides in bold indicate an alteration in the consensus ERE. EREc38, PR1148, pS2, and Fos-1211 were cloned into the pGL3-promoter luciferase reporter vector (Promega, Madison, WI, USA) as previously described (Klinge et al. 1997). Details of the EMSA experiments to determine ER-ERE binding affinity are provided in Kulakosky et al. (2002), Tyulmenkov et al. (2000), and Tyulmenkov \& Klinge $(2001 a, b)$.

\section{Cell culture, transient transfection, and reporter assays}

Chinese Hamster Ovary cells (CHO-K1) were purchased from ATCG (Manasas, VA, USA) and maintained in Iscove's modified Dulbecco's medium (IMDM) (Gibco/Invitrogen, Grand Island, NY, USA) supplemented with heat-treated, charcoal-stripped 10\% fetal bovine serum (Atlanta Biologicals, Norcross, GA, USA). All other cell culture reagents were purchased from Gibco-BRL (Grand Island, NY, USA). For transient transfection, CHO-K 1 cells were plated into 24-well plates at $1 \times 10^{5}$ cells/well with IMDM (without phenol red) supplemented with 10\% charcoal-stripped fetal bovine serum. The cells were transfected when $80 \%$ confluent with $0.25 \mu \mathrm{g}$ reporter construct containing the ERE, $5 \mathrm{ng}$ pRL-GMV $(\mathrm{RL}=$ Renilla luciferase from Promega, Madison, WI, USA), $10 \mathrm{ng}$ pCMV-human ER $\alpha$ or pCMV-rat ER $\beta$, graciously provided by Drs B S Katzenellenbogen and J-A Gustafsson respectively. The expression plasmid for NCoR was provided by Dr M Bagchi (Zhang et al. 1998). The expression plasmid for SMRT was provided by Dr B G Rowan (Coleman et al. 2003). The expression plasmids for SRG-1 and SRA were provided by Dr B W O'Malley (Lanz et al. 1999). The expression plasmid for CBP was provided by Dr M Hadzopoulou-Gladaras (Dell \& Hadzopoulou-Cladaras 1999). The expression plasmids for GRIP1, ACTR, GARM1, and PRMT1 were provided by Dr M Stallcup (Koh et al. 2001). The amounts of each of the coregulator plasmids used in transfection are indicated in the Figures and their legends. In experiments comparing the activity of a single coactivator with that achieved by co-transfecting two coactivators, 
coactivators were run alone or in combination within the same transfection to obviate differences between transient transfections.

The transient transfections were performed using Transfast (Promega) as previously described (Klinge et al. 1999, 2000, Tyulmenkov et al. 2000). The total amount of DNA transfected was kept constant using pcDNA3 (Invitrogen, Carlsbad, CA, USA) as 'filler DNA'. Cells were treated, in triplicate, $24 \mathrm{~h}$ later with ethanol $(\mathrm{EtOH}$,

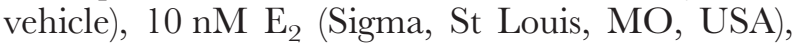
$100 \mathrm{nM}$ 4-hydroxytamoxifen (4-OHT) (Research Biochemicals International, Natick, MA, USA), or both $\mathrm{E}_{2}$ and 4-OHT. Cells were harvested $30 \mathrm{~h}$ later and luciferase and Renilla-luciferase (RL-luc) activities assayed using the Promega dual luciferase reporter assay (Klinge et al. 1997, 1999, Tyulmenkov et al. 2000). All data for transient transfections were normalized by RL-luc to account for transfection efficiency.

\section{Statistical analyses}

Statistical analyses were performed on foldinduction data values from multiple experiments (minimally three) in which each treatment was run in triplicate using either two-tailed Student's $t$-test or one-way ANOVA followed by Dunn's multiple comparison or Dunnett's post-hoc test using GraphPad Prism (GraphPad Software, Inc., San Diego, CA, USA).

CHO-K1 cells were transfected with expression vectors for coactivators, corepressors, $\mathrm{ER} \alpha$, ER $\beta$, and reporter vectors as described above. Whole cell extracts were prepared as described previously (Klinge et al., 2000). Protein concentrations were determined by BioRad's DCG (Lowry) assay (BioRad, Hercules, CA, USA) using BSA as a standard. Equal amounts of protein $(75 \mu \mathrm{g} /$ lane $)$ were separated by electrophoresis on $10 \%$ SDSPAGE gels. Proteins were transferred to polyvinylidene difluoride membranes (Pall Corporation, Ann Arbor, MI, USA). The blots were probed with primary antibodies: SRG-1 (GeneTex, San Antonio, TX, USA); GRIP1 and ACTR (both from US Biological, Swampscott, MA, USA); $\beta$-actin (Amersham, Arlington Heights, IL, USA); glyceraldehyde-3-phosphate dehydrogenase (GAPDH; Research Diagnostics, Inc., Flanders, NJ, USA). Immunoreactive complexes were visualized using SuperSignal West Pico Chemilumines- cent substrate from Pierce (Rockford, IL, USA) on Eastman Kodak (Rochester, NY, USA) BioMax ML film. Data were quantitated from scanned films using Un-Scan-It software (Klinge et al. 2001).

\section{GST-RID fusion protein preparation}

The plasmids pGEX-2-TK-SRC-1 (219-399), pGEX-2TK-TIF2 (623-986), and pGEX-2TKAIB1 (522-82) were graciously provided by Drs M Muylan and R Hilf of the University of Rochester (Yi et al. 2002). The plasmid pGEX-4T-1-NGoR was graciously provided by $\mathrm{Dr}$ A Hollenberg of Harvard University (Cohen et al. 2000). BL21 E. coli were used for expression of the GST-RID fusion proteins which were purified by GSH-Sepharose (Amersham Biosciences, Piscataway, NJ, USA) affinity chromatography as described previously (Klinge et al. 1997).

\section{EMSA}

Protein-DNA binding was measured by EMSA as previously reported (Klinge et al. 2001). Identical molar amounts of baculovirus-expressed human $\mathrm{ER} \alpha$ or $\mathrm{ER} \beta 1$, based on hydroxyapatite (HAP) assay results, were incubated with 150-500 fmol ${ }^{32}$ P-labeled $50 \mathrm{bp}$ oligomers EREc38, EREc13, pS2, PR1148, and Fos-1211. Binding reactions included $40 \mathrm{mM}$ Tris- $\mathrm{HCl}(\mathrm{pH} 7 \cdot 5), 10 \%$ glycerol, $0.75 \mu \mathrm{g} / \mu \mathrm{l}$ BSA, and $0.02 \mu \mathrm{g} / \mu \mathrm{l}$ poly $\mathrm{d}(\mathrm{I}-\mathrm{C})$ (Midland Certified Reagents, Midland, TX, USA), $111 \mathrm{mM} \mathrm{KCl,} 1 \mathrm{mM}$ EDTA, $1 \mathrm{mM}$ dithiothreitol, and $0.5 \mathrm{mM}$ phenylmethylsulfonyl fluoride. ER $\alpha$ and ER $\beta$-specific antibodies $(\mathrm{G}-20$ and Y19 from Santa Cruz Biotechnology, Santa Cruz, CA, USA) were included in selected reactions. Dried EMSA gels were analyzed using a Packard Instruments InstantImager (Meridian, CT, USA) and associated software, Packard Imager for Windows v2.04 (Tyulmenkov \& Klinge 2001b).

\section{Results}

\section{ERE sequence impacts ER $\alpha-$ and ER $\beta$-mediated transcriptional activity}

Transient cotransfection assays were performed in CHO-K1 cells to determine how the nucleotide sequence of the ERE affects the enhancer activity of $\operatorname{ER} \alpha$ and ER $\beta$. This cell line was selected 
because it requires exogenous $\mathrm{ER} \alpha$ or $\mathrm{ER} \beta$ to activate ERE-driven reporter gene expression (McInerney et al. 1996) and thus allows evaluation of the transcriptional response of each ER subtype in isolation with each ERE. We selected five different ERE-driven luciferase reporter constructs to examine possible differences in transactivation potential between $\mathrm{ER} \alpha$ and $\operatorname{ER} \beta$ based on DNA sequence (see Materials and methods for sequences). EREc38 is a consensus ERE that includes the commonly used Xenopus vit A2 ERE palindrome (Klinge et al. 1992). EREc13 is the minimal consensus 13 bp palindromic ERE (Klein-Hitpass et al. 1988). The natural, non-consensus, imperfectly palindromic EREs were taken from the human pS2, c-fos, and PR genes (Kulakosky et al. 2002). The cells were treated with $\mathrm{EtOH}$ vehicle control, $10 \mathrm{nM} \mathrm{E}$, $100 \mathrm{nM} 4-\mathrm{OHT}$, or both, and luciferase and RL-luc activities were assayed (Fig. 1). For each of the four EREs tested, $E_{2}$ increased luciferase expression above the basal level for both $\mathrm{ER} \alpha$ and ER $\beta$. Luciferase activity detected in the presence of 4-OHT was either at or below basal expression. Co-treatment with $\mathrm{E}_{2}$ and 4-OHT inhibited $\mathrm{E}_{2}$-induced reporter activity, indicating that the $\mathrm{E}_{2}$-induced activation is mediated specifically by $\mathrm{ER} \alpha$ and $\mathrm{ER} \beta$. ER $\alpha$ showed a greater $\mathrm{E}_{2}$-induced fold-induction of reporter gene activity with the EREc38, EREc13, and pS2 EREs compared with ER $\beta$. However, the fold-induction of luciferase by $\operatorname{ER} \alpha$ and $\operatorname{ER} \beta$ was similar on the Fos-1211 and PR1148 EREs. These results indicated that the ERE sequence differentially impacts the $\mathrm{E}_{2}$-dependent transcriptional activities of $\operatorname{ER} \alpha$ and $\operatorname{ER} \beta$.

\section{Coactivators impact basal transcription activity}

We have previously reported that the ERE nucleotide sequence altered ER $\alpha$ conformation as assessed by protease digestion studies (Klinge et al. 2001, Tyulmenkov \& Klinge 2001a). Here we tested the hypothesis that the observed ERE sequence-induced alterations in ER conformation may alter ER-coregulator interactions in vivo. This is the first study to directly compare coregulator interactions with $\mathrm{ER} \alpha$ and $\mathrm{ER} \beta$ in response to single copy EREs in the context of their natural flanking sequence in a functional assay. Further, although coactivators have been shown to impact $\mathrm{ER} \alpha$ and $\mathrm{ER} \beta$ activity in transfected cell lines using
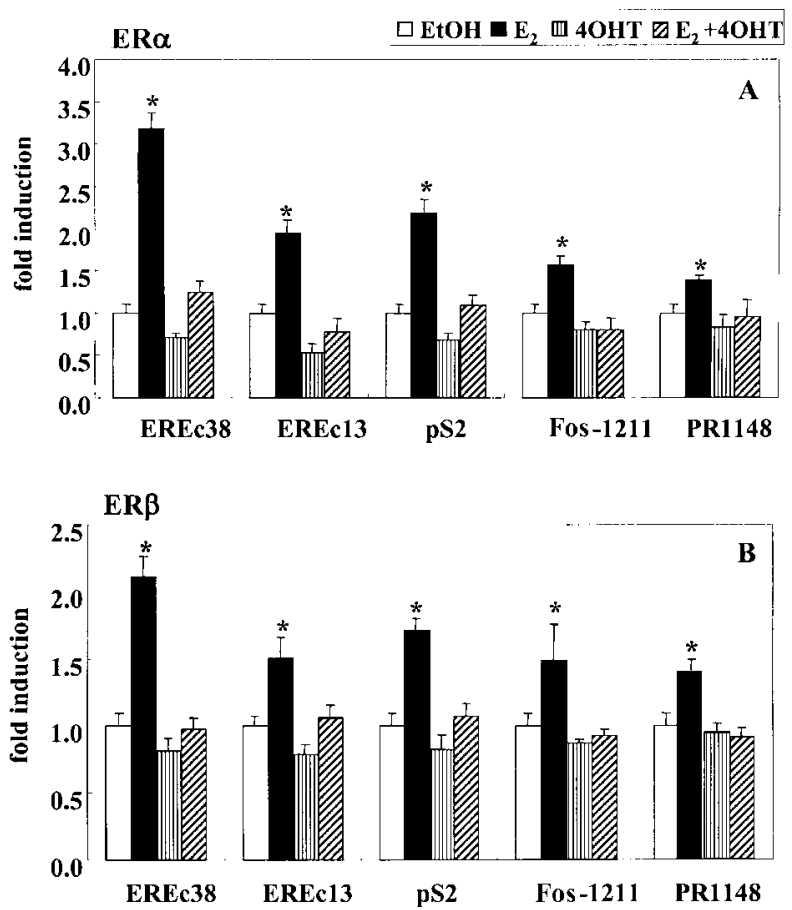

Figure 1 ERE sequence impacts $E R \alpha$ and $E R \beta$ transcriptional activity. $\mathrm{CHO}-\mathrm{K} 1$ cells were co-transfected with (A) ER $\alpha$ or (B) ER $\beta$ plus the indicated $p G L 3-E R E-l u c i f e r a s e$ reporter and $p R L-C M V$ as described in Materials and methods. Twenty-four hours after transfection, the cells were treated with $\mathrm{EtOH}, 10 \mathrm{nM} \mathrm{E}_{2}, 100 \mathrm{nM} 4-\mathrm{OHT}$, or $10 \mathrm{nM} \mathrm{E}_{2}$ plus $100 \mathrm{nM} 4-\mathrm{OHT}$ for $30 \mathrm{~h}$. Cell extracts were prepared and assayed as described in Materials and methods. Data are displayed as luciferase activity divided by the $\mathrm{RL}$-luc activity in each well and normalized by $\mathrm{EtOH}$ control (which is set to 1). Within each experiment, each treatment was performed in triplicate. The data shown are the means \pm S.E.M. from at least 11 separate experiments. ${ }^{*} P<0.05, \mathrm{E}_{2}$ values that are statistically different from the $\mathrm{EtOH}$ control value.

different ERE reporters, most prominently multiple tandem copies of the vit A2 ERE, few investigators have separated the effect of coregulators on the basal activity of ER on the reporter gene assayed versus that stimulated by $\mathrm{E}_{2}$ (reviewed in Klinge 2003).

First, we examined the effect of coregulators on basal, ligand-independent ER $\alpha$ activity by measuring luciferase expression from each ERE (Fig. 2). CHO-K1 contains endogenous SRC-1, GRIP1, ACTR, CBP, and SMRT (Western data not shown). To account for endogenous expression of coregulators, each ER-ERE combination tested 
A

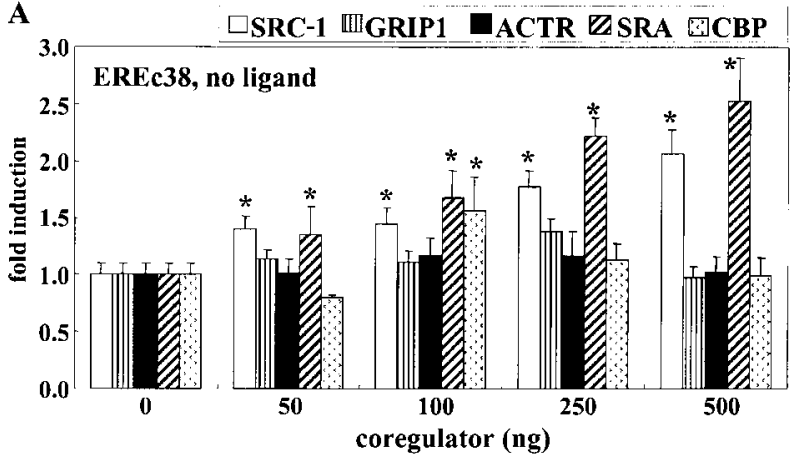

B

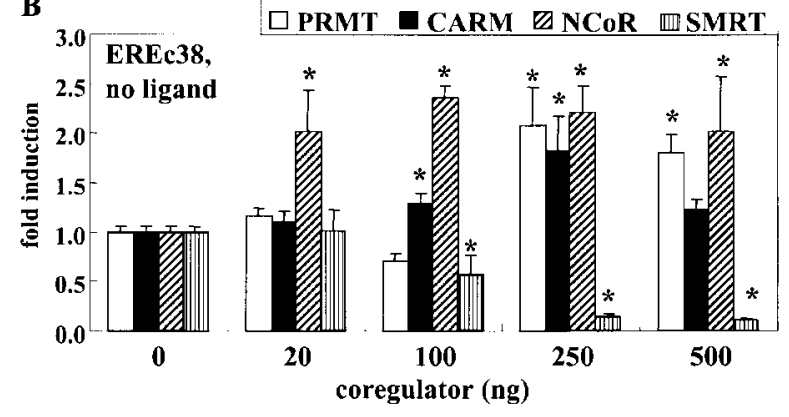

E $4 . 0 \longdiv { \text { EREc13, no ligand } }$

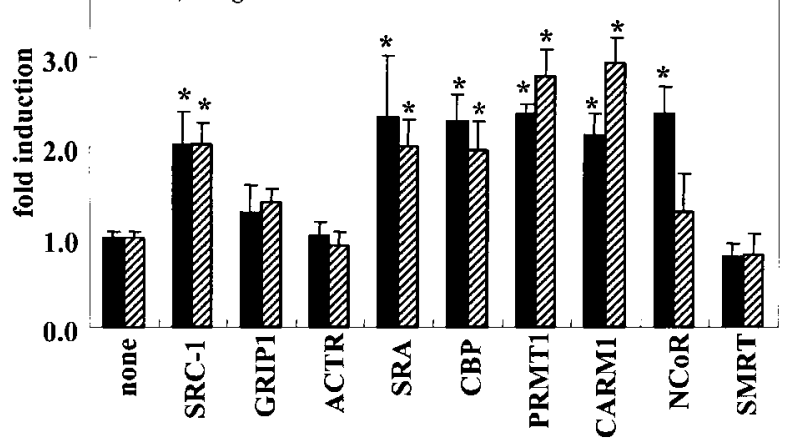

F

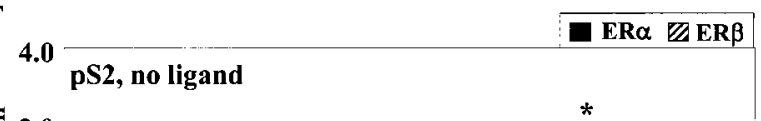

C
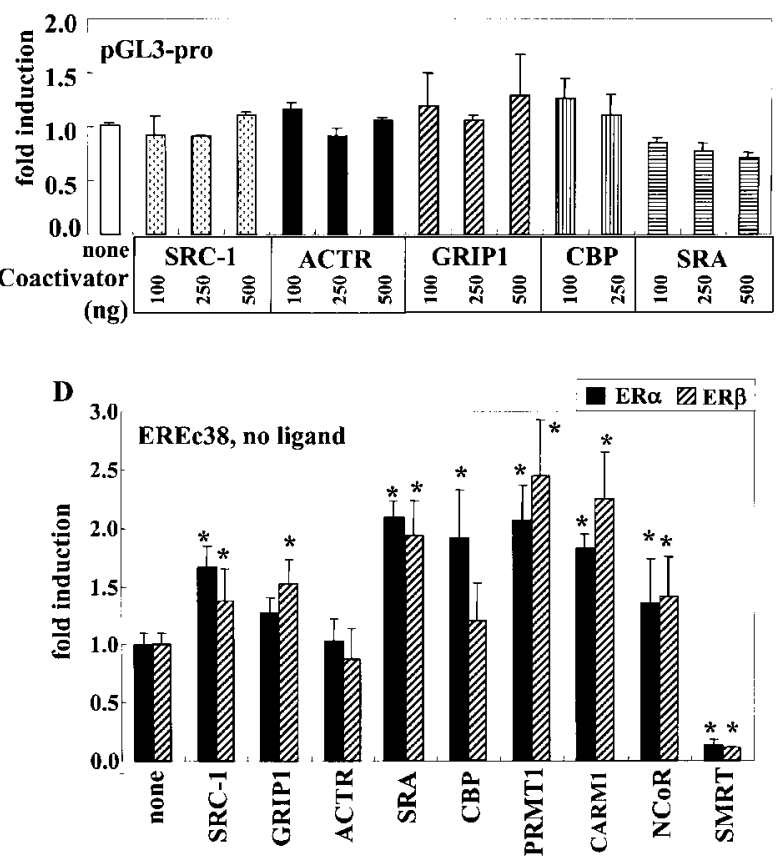

G
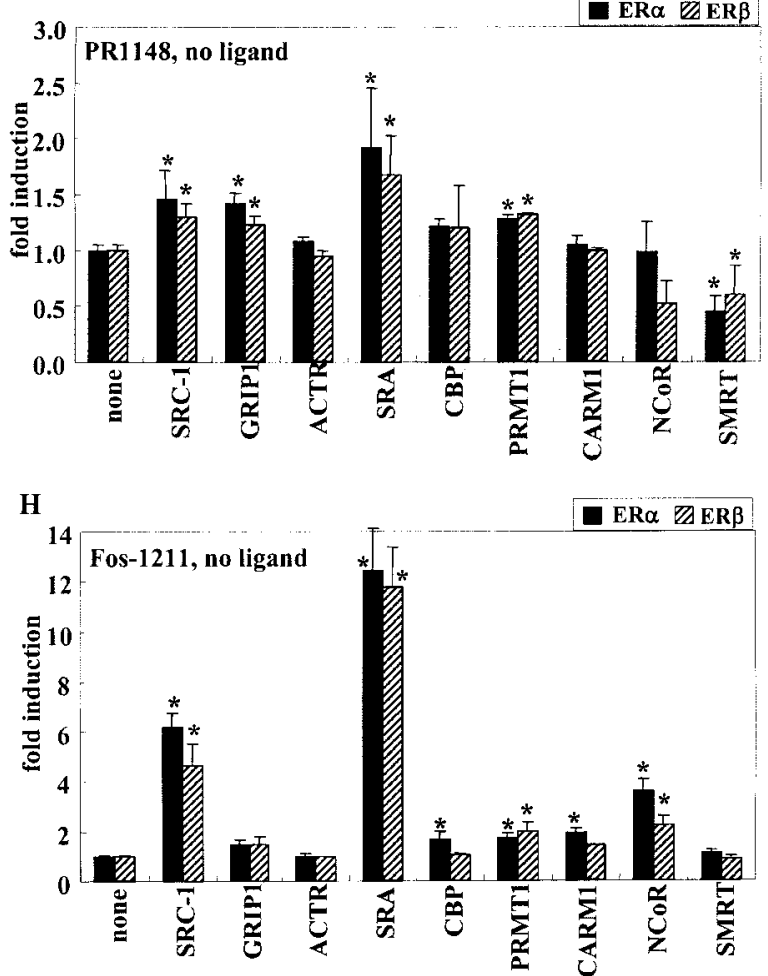
was treated with ethanol in the absence of co-transfected coregulators. This control level of reporter activity was set to 1 . SRC-1 and SRA increased basal $\mathrm{ER} \alpha$ activity in a concentrationdependent manner from EREc38 (Fig. 2A). CBP significantly stimulated basal activity only at 100 ng. PRMT1, CARM1, and NCoR stimulated basal ER $\alpha$ transcriptional activity from EREc38 whereas SMRT repressed the basal ER $\alpha$ activity in a concentration-dependent manner (Fig. 2B). Noteworthy is the fact that none of the coregulators affected the basal activity of $\operatorname{ER} \alpha$ or $\operatorname{ER} \beta$ on the parental pGL3-pro-luciferase vector without EREs (Fig. 2C and data not shown). None of the coregulators with the exception of $\mathrm{CBP}$ had any effect on either firefly luciferase activity from pGL3-1 EREc38 or the other reporter vectors or RL-luc activity. Since CBP did not stimulate luciferase activity from the pGL3-pro plasmid (Fig. 2C), despite the presence of one cyclic AMP response element binding protein (CREB) binding site in the luciferase gene and another in the ampicillain resistance gene (Promega; personal communication), the stimulation of luciferase activity from pGL3-1 EREc38 by CBP must be mediated by the inclusion of EREc38 which contains a cyclic AMP response element (CRE). Nonetheless, because our data are normalized for CBP stimulation on the ERE reporters in the absence of ER, the stimulation of ligandindependent ER $\alpha$ basal activity by SRG-1, SRA, CBP, PRMT1, CARM1, and NCoR (Fig. 2A and $\mathrm{B})$ is mediated by ERE-ER $\alpha$ interaction. Based on the work of other investigators (Webb et al. 2003), we suggest that these effects of coactivators on unliganded ER may be mediated through the $\mathrm{N}$-terminal activation domain (AF-1) which is ligand independent.

Next, we compared the ligand-independent activity of $\operatorname{ER} \alpha$ and $\operatorname{ER} \beta$ with a fixed amount of each coregulator on EREc38 in transfected CHO-K1 cells (Fig. 2D). SRG-1, SRA, PRMT1,
CARM1, and NCoR stimulated the basal activity of $\mathrm{ER} \alpha$ and $\mathrm{ER} \beta$. GRIP1 stimulated unliganded $\mathrm{ER} \beta$ but not ER $\alpha$ and conversely CBP stimulated the activity of unliganded $\mathrm{ER} \alpha$ but not $\mathrm{ER} \beta$. SMRT repressed the basal activity of both unliganded $\mathrm{ER} \alpha$ and $\mathrm{ER} \beta$.

To address the role of the ERE nucleotide sequence in the effect of coregulators on ligandindependent ER $\alpha$ and $\mathrm{ER} \beta$, cells were transfected with EREc13, pS2, PR1148, and Fos-1211 EREs and a fixed amount of each coregulator (Fig. 2E-H). Each ERE showed both ER subtype- and coactivator-specific differences in transcriptional response. The most striking ligand-independent stimulation of $\mathrm{ER} \alpha$ and $\mathrm{ER} \beta$ activity was with SRA and SRC-1 on Fos-1211. ACTR did not stimulate either $\operatorname{ER} \alpha$ or $\operatorname{ER} \beta$ on any of the EREs. ER $\alpha$ and ER $\beta$ showed different responses to NGoR on EREc13 and pS2 and to PRMT1 and CARM1 on pS2.

To address the role of $\mathrm{E}_{2}$ in mediating functional interaction of $\mathrm{ER} \alpha$ and $\mathrm{ER} \beta$ with coregulators, in all subsequent experiments cells were transfected with each coregulator and treated with $\mathrm{EtOH}$ and $10 \mathrm{nM} \mathrm{E} \mathrm{E}_{2}$; the luciferase activity detected with $\mathrm{E}_{2}$ was normalized by that for EtOH. Thus, any effect of a coregulator on basal, ligand-independent ER transcription was excluded from subsequent analysis. This allows comparison of the effect of a coregulator on ligand-activated ER transcription independent of effect of that coregulator on ligand-independent (basal) transcription from the reporter.

\section{ERE sequence impacts coactivator-mediated transactivation by $E_{2}-E R \alpha$ and $E_{2}-E R \beta$}

Next, we compared how different ERE sequences affected the ability of coregulators to affect $\mathrm{E}_{2}$-stimulated activity with $\mathrm{ER} \alpha$ or $\mathrm{ER} \beta$. Figure $3 \mathrm{~A}$ shows that of the tested coactivators, only SRC-1 stimulated $\mathrm{E}_{2}$-induced $\mathrm{ER} \alpha$ activity on the vit $\mathrm{A} 2$

Figure 2 Coregulators influence ligand-independent ER activity. In (A and B) CHO-K1 cells were transfected with $\mathrm{ER} \alpha$, EREc38-luciferase reporter, and the amounts of the indicated coactivators. In (C) CHO-K1 cells were transfected with ER $\alpha$, pGL3-pro-luciferase reporter (no EREs), and the amounts of the indicated coactivators. In $(\mathrm{D}-\mathrm{H}) \mathrm{CHO}-\mathrm{K} 1$ cells were transfected with the indicated ERE-luciferase reporter, ER $\alpha$ or ER 3 , and $250 \mathrm{ng}$ of the indicated coregulators. All cells were co-transfected with RL-luc reporter control. Cells were treated with EtOH for $30 \mathrm{~h}$ and processed as described in Fig. 1 and in Materials and methods. Values are the fold-induction over EtOH activity in the absence of added coregulator and are the means \pm S.E.M. of three to eight different experiments. ${ }^{\star} P<0 \cdot 05$, values that are statistically different from the control value. 

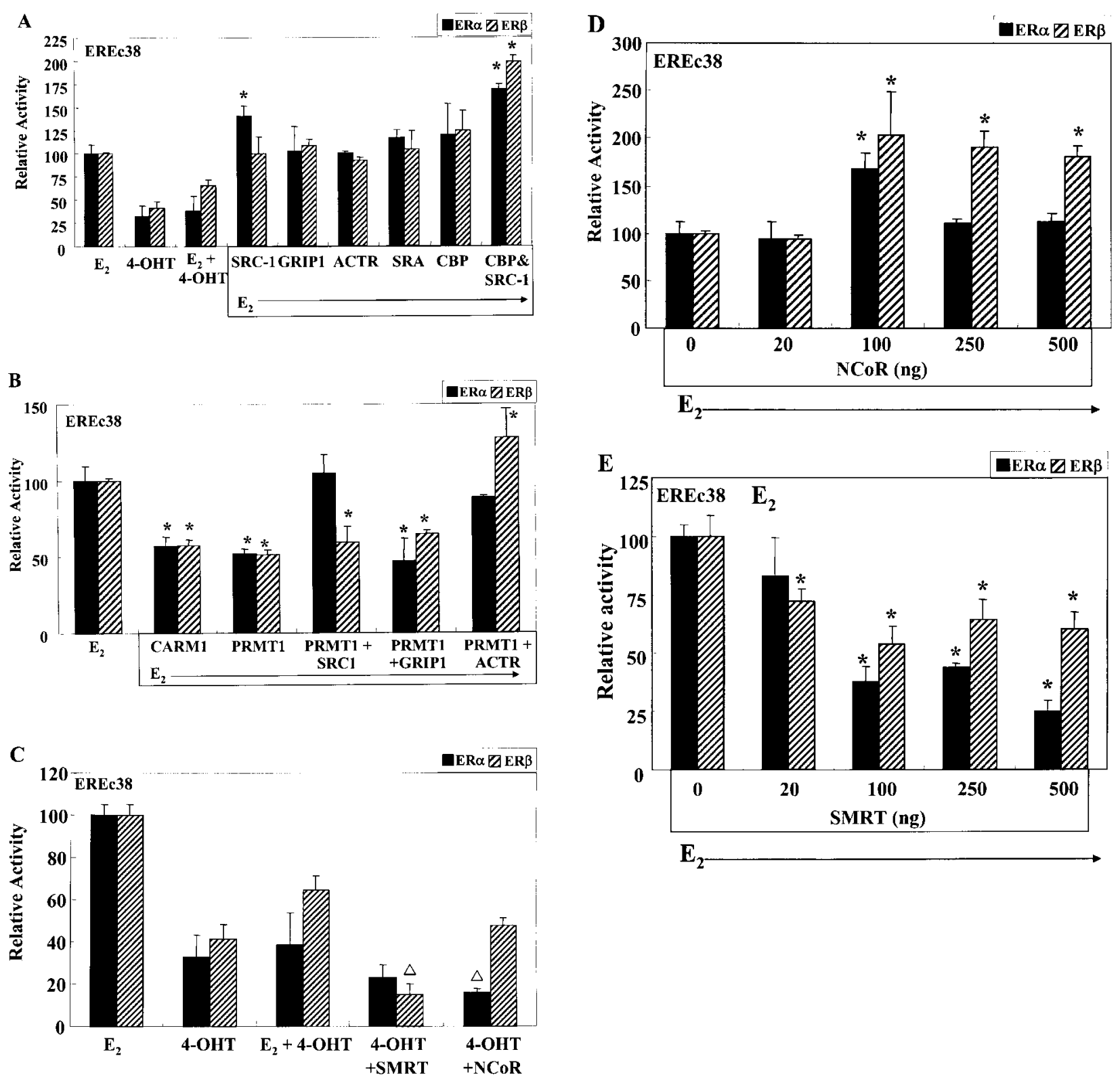

Figure 3 Transcriptional response of $\mathrm{ER} \alpha$ and $\mathrm{ER} \beta$ to coregulators on EREc38. CHO-K1 cells were transfected with $\mathrm{ER} \alpha$ or ER $\beta$ and EREc38-luciferase reporter, $\mathrm{pRL}-\mathrm{CMV}$, and $250 \mathrm{ng}$ of the indicated coregulator as described in Materials and methods. Cells were treated with $\mathrm{EtOH}, 10 \mathrm{nM} \mathrm{E}_{2}, 100 \mathrm{nM} 4-\mathrm{OHT}$, or both $\mathrm{E}_{2}$ and 4-OHT, as indicated, for $30 \mathrm{~h}$ and processed as described in Fig. 1 and in Materials and methods. The maximal activity with $10 \mathrm{nM} \mathrm{E}_{2}$ was set at 100 (absolute fold values are shown in Fig. 1). Values are the means \pm S.E.M. of three to eight different experiments. $(\mathrm{A}, \mathrm{B}, \mathrm{D}$, and $\mathrm{E}){ }^{*} P<0.05$, values that are statistically different from the $\mathrm{E}_{2}$-induced value for that receptor subtype in the absence of coregulator. (C) $\Delta P<0.05$, values that are significantly different (Student's $t$-test) between the 4-OHT activity without and with SMRT or NCoR.

ERE (EREc38). Singly, none of the coactivators stimulated $\operatorname{ER} \beta$ activity. The combination of CBP and SRC-1 synergistically activated $\mathrm{E}_{2}$-induced $\mathrm{ER} \beta$ but not $\mathrm{ER} \alpha$ activity. In contrast, both
CARM1 and PRMT1 inhibited ER $\alpha-$ and ER $\beta$-induced transcriptional activity (Fig. 3B). This result contrasts to the stimulation of basal activity of $\mathrm{ER} \alpha$ and $\mathrm{ER} \beta$ by CARM1 and PRMT1. 
Cotransfection of SRC-1 relieved PRMT1mediated repression of $\mathrm{ER} \alpha$, but not $\mathrm{ER} \beta$ activity. This result agrees with the ER $\alpha$-selective stimulation by SRC-1 shown in Fig. 3A. ACTR relieved PRMT1-mediated repression of both $\operatorname{ER} \alpha$ and ER $\beta$. GRIP1 did not relieve the PRMT1-mediated repression of either $\mathrm{ER} \alpha$ and $\mathrm{ER} \beta$.

4-OHT binds ER $\alpha$ and ER $\beta$ with comparable affinity (Kuiper et al. 1997). However, 4-OHT only exhibits agonist activity with ER $\alpha$ at EREs in certain cell types (Weatherman \& Scanlan 2001). Our experiments show that 4-OHT had no agonist activity with either $\operatorname{ER} \alpha$ or $\operatorname{ER} \beta$ and inhibited $\mathrm{E}_{2}$-induced transcription by both $\mathrm{ER} \alpha$ and $\operatorname{ER} \beta$ in CHO-K1 cells (Fig. 3C). The corepressor SMRT decreased 4-OHT activity with ER $\beta$. In contrast, the corepressor NCoR further decreased 4-OHT$\mathrm{ER} \alpha$ but not $\mathrm{ER} \beta$ activity. These results indicate that 4-OHT-occupied ER $\alpha$ and ER $\beta$ differ in their interactions with corepressors SMRT and NCoR. Our data are in agreement with phage display experiments showing differences in the conformation of 4-OHT-occupied $\mathrm{ER} \alpha$ and $\mathrm{ER} \beta$ in vitro (Paige et al. 1999).

Recently, the corepressors NCoR and SMRT were shown to interact directly with ACTR and facilitate thyroid receptor-ACTR binding in vitro and in a mammalian two-hybrid assay ( $\mathrm{Li}$ et al. 2002). We tested the hypothesis that addition of SMRT or NCoR to cells transfected with ER $\alpha$ or $\mathrm{ER} \beta$ and treated with $\mathrm{E}_{2}$ would result in increased reporter gene expression. NGoR increased $\mathrm{E}_{2}{ }^{-}$ induced activity by $\mathrm{ER} \alpha$ only with the addition of $100 \mathrm{ng}$. In contrast, ER $\beta$ activity was increased with $100 \mathrm{ng}$ and higher amounts of NCoR (Fig. 3D). SMRT decreased $\mathrm{E}_{2}$-induced activity by $\mathrm{ER} \alpha$ or $\mathrm{ER} \beta$ in a concentration-dependent manner that appeared to saturate for $\mathrm{ER} \beta$ at $100 \mathrm{ng}$ (Fig. 3E). These data indicated that under the assay conditions used NGoR acts as a coactivator whereas SMRT acts as a corepressor of $\operatorname{ER} \alpha$ and $\operatorname{ER} \beta$.

EREc13, the minimal consensus ERE (KleinHitpass et al. 1988), binds ER $\alpha$ and $\operatorname{ER} \beta$ with significantly lower affinity than ERE palindromes containing $15 \mathrm{bp}$ or more, i.e. $K_{\mathrm{d}} 1.1 \mathrm{nM}$ and $1.7 \mathrm{nM}$ versus $0.11 \mathrm{nM}$ and $0.13 \mathrm{nM}$ for $\mathrm{ER} \alpha$ and ER $\beta$ respectively (Table 1 and (Kulakosky et al. 2002)). GRIP1, ACTR, and SRA increased $\mathrm{E}_{2}$-ER $\alpha$ activity on EREc13 (Fig. 4). In contrast, none of the coactivators stimulated $\mathrm{E}_{2}$-ER $\beta$ activity. These results differ from stimulation of unliganded ER $\beta$ by SRA (Fig. 2E). However, the combination of SRC-1 and CBP stimulated $\mathrm{E}_{2}$-induced $\mathrm{ER} \beta$ activity. $\mathrm{NCoR}$ stimulated $\mathrm{E}_{2}$ induced $\operatorname{ER} \beta$ but not $\operatorname{ER} \alpha$ activity. These data indicated that $\operatorname{ER} \alpha$ and $\operatorname{ER} \beta$ show functional differences in coactivator interaction on a minimal ERE reporter in $\mathrm{E}_{2}$-treated cells, a result concordant with differential interaction of small peptides mimicking coregulator interaction sequences with $\mathrm{ER} \alpha$ and $\mathrm{ER} \beta$ in vitro (Hall et al. 2000). Furthermore, comparison of the coactivator stimulation of $\mathrm{ER} \alpha$ and $\mathrm{ER} \beta$ on EREc38 versus EREc13 (Table 1) indicates that the length of the ERE palindrome differentially impacts $\operatorname{ER} \alpha$ and ER $\beta$ interaction with coregulators, a result predicated by work using phage display to examine conformational differences between $\mathrm{ER} \alpha$ and ER $\beta$ bound to different EREs (Hall et al. 2002).

Finally, we examined the effect of coregulators on the activities of $\operatorname{ER} \alpha$ and $\operatorname{ER} \beta$ bound to natural, non-palindromic EREs from the human pS2, PR, and c-fos genes (Fig. 5). Notably, certain coactivators stimulated $\mathrm{E}_{2}$-ER transcription in an ER subtype- and ERE sequence-dependent manner. $\mathrm{E}_{2}$-induced $\mathrm{ER} \alpha$ activity was enhanced $30 \%$ by ACTR on pS2, but not on Fos-1211 or PR1148. $\mathrm{E}_{2}$-induced $\mathrm{ER} \beta$ activity on $\mathrm{pS} 2$ was enhanced by SRC-1, GRIP1, SRA, GBP, CARM1, and PRMT1 in the presence of GRIP1. In contrast, only CBP stimulated $\mathrm{E}_{2}$-induced $\mathrm{ER} \beta$ activity on PR1148. $E_{2}$-induced ER $\alpha$ activity on PR 148 was inhibited by cotransfection with SRA. ER $\beta$ activity on PR1148 was reduced by CARM1 and PRMT1. PRMT1 was reported to have stronger coactivator activity when co-transfected with p160 coactivators compared with GARM1 (Koh et al. 2001). The inhibitory effect of PRMT1 on $\mathrm{E}_{2}$-induced ER $\beta$ activity on PR1148 was relieved by cotransfection with ACTR, but not by SRG-1 or GRIP1.

Coactivators showed the least impact on $\mathrm{E}_{2}$-stimulated $\mathrm{ER} \alpha$ or $\mathrm{ER} \beta$ activity on Fos-1211 (Fig. 5C). This is in contrast to the high stimulation of unliganded ER $\alpha$ or ER $\beta$ activity on Fos-1211 (Fig. 2H). Only GRIPl and SRA enhanced $\mathrm{E}_{2}$-induced $\mathrm{ER} \alpha$ and $\mathrm{ER} \beta$ activity respectively (Fig. 5C). SRC-1 inhibited $\mathrm{E}_{2}$-ER $\alpha$ activity. CBP inhibited $\mathrm{E}_{2}$-induced $\operatorname{ER} \alpha$ and $\operatorname{ER} \beta$ activity. The lack of effect of coactivators on $\mathrm{E}_{2}$-induced reporter activity from the non-palindromic Fos-1211 ERE may be the result of the reduced ER binding affinity (Table 1) which would theoretically 
Table 1 Effect of ERE sequence on $E_{2}$-induced transcriptional activity by $E R \alpha$ and ER $\beta$. $K_{d}$ values are the means \pm S.E.M. of four to six separate EMSA determinations as described (Tyulmenkov et al. 2000, Klinge et al. 2001, Tyulmenkov \& Klinge 2001b, Kulakosky et al. 2002). The effect of the indicated coactivator on $\mathrm{E}_{2}$-stimulated $\mathrm{ER} \mathrm{a}$ or ER $\beta$ transcriptional activity is a summary of the relevant data from the transient transfection assays performed in CHO-K1 cells as shown in Figs 3-6

\begin{tabular}{|c|c|c|c|c|c|c|c|}
\hline & $\begin{array}{l}\text { ERE palindrome } \\
(c=\text { consensus, } \\
\text { perfectly } \\
\text { palindromic ERE } \\
\text { (Klinge 2001)) }\end{array}$ & $\begin{array}{l}\text { ER } \boldsymbol{\alpha} \\
\boldsymbol{K}_{\mathbf{d}}(\mathrm{nM})\end{array}$ & $\begin{array}{l}\text { ER } \beta \\
\boldsymbol{K}_{\mathrm{d}}(\mathrm{nM})\end{array}$ & $\begin{array}{l}\text { ER } \alpha \\
\text { stimulated } \\
\text { by }\end{array}$ & $\begin{array}{l}\text { ER } \alpha \\
\text { inhibited } \\
\text { by }\end{array}$ & $\begin{array}{l}\text { ER } \beta \\
\text { stimulated } \\
\text { by }\end{array}$ & $\begin{array}{l}\text { ER } \beta \\
\text { inhibited } \\
\text { by }\end{array}$ \\
\hline $\begin{array}{l}\text { ERE } \\
\text { EREc38 }\end{array}$ & EREc19 & $0.11 \pm 0.02$ & $0.64 \pm 0.02$ & $\begin{array}{l}\text { SRC-1 } \\
\text { NCoR }\end{array}$ & $\begin{array}{l}\text { CARM1 } \\
\text { PRMT1 } \\
\text { (PRMT+ } \\
\text { GRIP1) }\end{array}$ & $\begin{array}{l}\text { NCoR } \\
\text { SMRT } \\
\text { (PRMT1+ } \\
\text { ACTR) }\end{array}$ & $\begin{array}{l}\text { CARM1 } \\
\text { PRMT1 } \\
\text { (PRMT+ } \\
\text { SRC-1) } \\
\text { (PRMT+ } \\
\text { GRIP1) }\end{array}$ \\
\hline EREc13 & EREc13 & $10 \cdot 7 \pm 0 \cdot 07$ & $15 \cdot 5 \pm 2 \cdot 1$ & $\begin{array}{l}\text { SRA, } \\
\text { GRIP1 }\end{array}$ & & $\begin{array}{l}\mathrm{NCoR} \\
\text { (CBP+ } \\
\text { SRC-1) }\end{array}$ & \\
\hline pS2 & $\begin{array}{l}\text { EREc15, two } \\
\text { nucleotide } \\
\text { changes in the } \\
3^{\prime} \text { half-site }\end{array}$ & $1.06 \pm 0.02$ & $3 \cdot 0 \pm 0.6$ & ACTR & NCoR & $\begin{array}{l}\text { SRC-1 } \\
\text { GRIP1 } \\
\text { SRA } \\
\text { CBP } \\
\text { CARM1 } \\
\text { (PRMT1+ } \\
\text { GRIP1) }\end{array}$ & $\begin{array}{l}\text { (PRMT1+ } \\
\text { ACTR) }\end{array}$ \\
\hline PR1148 & $\begin{array}{l}\text { EREc15, four } \\
\text { nucleotide } \\
\text { changes in the } \\
3^{\prime} \text { half-site }\end{array}$ & $3 \cdot 3 \pm 0.3$ & $29 \cdot 1 \pm 5 \cdot 4$ & $\begin{array}{l}\text { SRC-1 } \\
\text { CBP }\end{array}$ & $\begin{array}{l}\text { SRA } \\
\text { SMRT }\end{array}$ & $\begin{array}{l}\text { CBP } \\
\text { NCoR }\end{array}$ & $\begin{array}{l}\text { CARM1 } \\
\text { PRMT1 } \\
\text { (PRMT1+ } \\
\text { SRC-1) } \\
\text { (PRMT1+ } \\
\text { GRIP1) } \\
\text { SMRT }\end{array}$ \\
\hline Fos-1211 & $\begin{array}{l}\text { EREc13, two } \\
\text { nucleotide } \\
\text { changes in the } \\
5^{\prime} \text { half-site }\end{array}$ & $328 \pm 38$ & $240 \pm 24$ & GRIP1 & $\begin{array}{l}\text { SRC-1 } \\
\text { CBP } \\
\text { NCoR }\end{array}$ & SRA & $\begin{array}{l}\text { CBP } \\
\text { NCoR } \\
\text { SMRT }\end{array}$ \\
\hline
\end{tabular}

decrease ER-ERE occupancy ('on time') and therefore reduce assembly of the coactivator complex.

We also tested the effect of addition of NCoR or SMRT on $\mathrm{E}_{2}$-induced reporter activity from the non-palindromic EREs (Fig. 5D). As with the data on coactivators, NGoR and SMRT differed in their effect on transcription in an ER subtype- and ERE sequence-dependent manner. NCoR decreased $\mathrm{E}_{2}$-ER $\alpha$ activity from $\mathrm{pS} 2$ and Fos-1211, but not PR1148. NGoR also decreased $\mathrm{E}_{2}$-ER $\beta$ activity from Fos-1211. NCoR enhanced $\mathrm{E}_{2}$-ER $\beta$ activity with PR1148. SMRT inhibited $\mathrm{E}_{2}$-induced ER $\alpha$ activity from PR 1148 and $\mathrm{ER} \beta$ activity from Fos-1211 and PR1148. We concluded that SMRT and NGoR differentially impact $\mathrm{E}_{2}$-induced tran- scriptional activity in an ER subtype- and ERE sequence-dependent manner.

A possible explanation for the differences detected between the effects of the coactivators on $\mathrm{ER} \alpha$ or $\mathrm{ER} \beta$ transcriptional activity is altered expression of the coactivators under different experimental conditions. To determine whether the expression of the coregulators was equal in transfected cells, Western blots were performed (Fig. 6). Densitometric analysis of the SRC-1, GRIP1, or ACTR/ $\beta$-actin ratio in repeated transient transfection experiments revealed no statistical differences in the amounts of coactivator expressed in cells transfected with either ER $\alpha$ or $\mathrm{ER} \beta$ and that there was no effect of ERE sequence on the expression of transfected SRC-1, GRIP1, or 


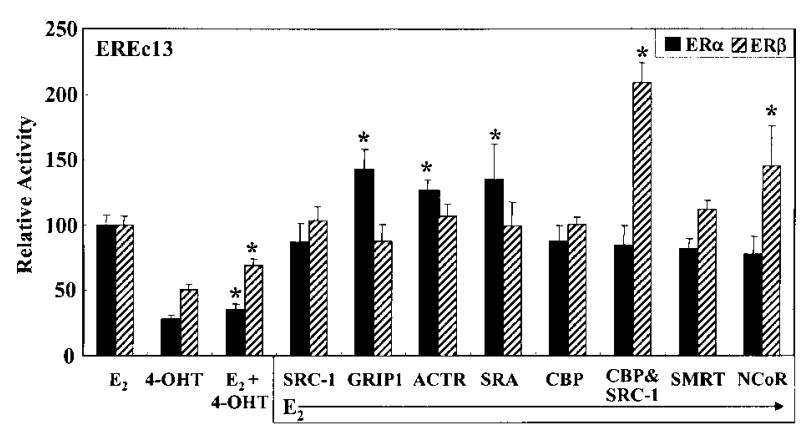

Figure 4 Transcriptional response of $\mathrm{ER} \alpha$ and $\operatorname{ER} \beta$ to coregulators on EREc13. CHO-K1 cells were transfected with ER $\alpha$ or ER $\beta$, EREc13-luciferase, $\mathrm{pRL}-\mathrm{CMV}$, and $250 \mathrm{ng}$ of the indicated coregulators as described in Materials and methods and Figs 1 and 3 . Values are the means \pm S.E.M. of three to nine different experiments. ${ }^{*} P<0.05$, values that are statistically different from the $E_{2}$-induced value for that receptor subtype in the absence of coregulator.

ACTR in GHO-K1 cells. This obviates differences in coregulator expression as an explanation for the observed differences in transcriptional activity seen with the different ERE reporters and between ER $\alpha$ or $\operatorname{ER} \beta$.

A possible explanation for the small differences in the effects of the coactivators on $\mathrm{ER} \alpha$ or $\mathrm{ER} \beta$ transcriptional activity with different EREs is that the if endogenous levels of a particular coregulator are already high, our experiments may not pick up any further effect of transfection of additional coregulator. Evidence that the effect of ER-coregulator interactions is not already saturated can be seen in Fig. 2 for SRG-1, SRA, CBP, CARM1, PRMT1, NGoR, and SMRT which stimulated unliganded $\mathrm{ER} \alpha$ and in some cases $\mathrm{ER} \beta$ transcriptional activity. Further, GRIP1 stimulated unliganded ER $\alpha$ and ER $\beta$ on PR1148 (Fig. 2 G) and ACTR stimulated ER $\alpha$ activity on EREc13 (Fig. 4) and pS2 (Fig. 5A). Thus, each of the coregulators studied stimulated $\mathrm{ER} \alpha$ and $\mathrm{ER} \beta$ activity on at least one transfected ERE reporter. If the response was already saturated for a particular coregulator, then no added stimulation would be seen under any circumstance.

\section{Synergism of combinations of coactivators with ER $\alpha$ and ER $\beta$ varies with ERE sequence}

Coactivators including CBP, SRA, CARM1, and PRMT1 are recruited to target gene promoters through their interaction with p160 family coactivators interacting directly with $\mathrm{ER}$ and other nuclear receptors (NR) (Teyssier et al. 2002). To test whether SRA synergized with p160 coactivators to stimulate $\mathrm{E}_{2}$-dependent transcription in an ERE sequence-dependent manner, CHO-K1 cells were transfected with either ER $\alpha$ or ER $\beta$, plus SRA, alone or in combination with SRC-1, GRIP1, or ACTR with different ERE reporters (Fig. 7). SRA showed no synergism with AGTR (compare with SRA and ACTR alone in Figs 3A, 4, and 5). GRIP1 synergized with SRA for ER $\alpha$ only on the Fos-1211 ERE (compare with GRIP1 and SRA alone in Fig. 5G). In contrast, SRA synergized with GRIP1 for ER $\beta$ on EREc38, EREc13, and Fos-1211 (compare with data in Figs 3A, 4, and 5C). Lastly, SRA synergized with SRC-1 for ER $\beta$ on EREc13 (compare with SRA and SRC-1 alone in Fig. 4).

\section{Coactivator RIDs show ER subtype- and ERE sequence-dependent ER interaction in vitro}

Since coregulators showed differential effects on $\mathrm{ER} \alpha$ and $\mathrm{ER} \beta$ transcriptional activity in an ERE sequence-dependent manner in transfected cells, we tested whether the RIDs of selected p160 coactivators showed ERE sequence-dependent interaction with $\mathrm{ER} \alpha$ and $\mathrm{ER} \beta$ in EMSAs. GST-fusion proteins containing the RIDs of SRG-1, GRIP1, ACTR, or NGoR were incubated with $\mathrm{E}_{2}$-occupied $\mathrm{ER} \alpha$ or $\mathrm{ER} \beta$ and different EREs in vitro. The sequence of the GST-RIDs and their location within the coregulator is shown in Table 2. As a negative control, each GST-RID was incubated with each ERE in the absence of ER. None of the GST-RIDs interacted with the EREs (Fig. 8 and data not shown). Figure 8 shows representative EMSAs for $\operatorname{ER} \alpha$ and $\operatorname{ER} \beta$ binding to the pS2 ERE with or without added GST-ACTR or GST-GRIP1.

Addition of GST-ACTR resulted in the appearance of an ERE-bound complex with slowed migration for both $\mathrm{ER} \alpha$ and $\mathrm{ER} \beta$ bound to pS2-ERE (Fig. 8) and EREc38 (Fig. 9A and B). In contrast, only the migration of ER $\alpha$-EREc13 was slowed by GST-ACTR (Fig. 9C and D). The amount of 'supershifted', i.e. complex with slowed migration, ACTR-ER $\alpha$-pS2 complex was greater than for ER $\beta$ (Fig. 8C and D). The total amount of ER $\alpha$-bound EREc13 pS2, and EREc38 complexes 

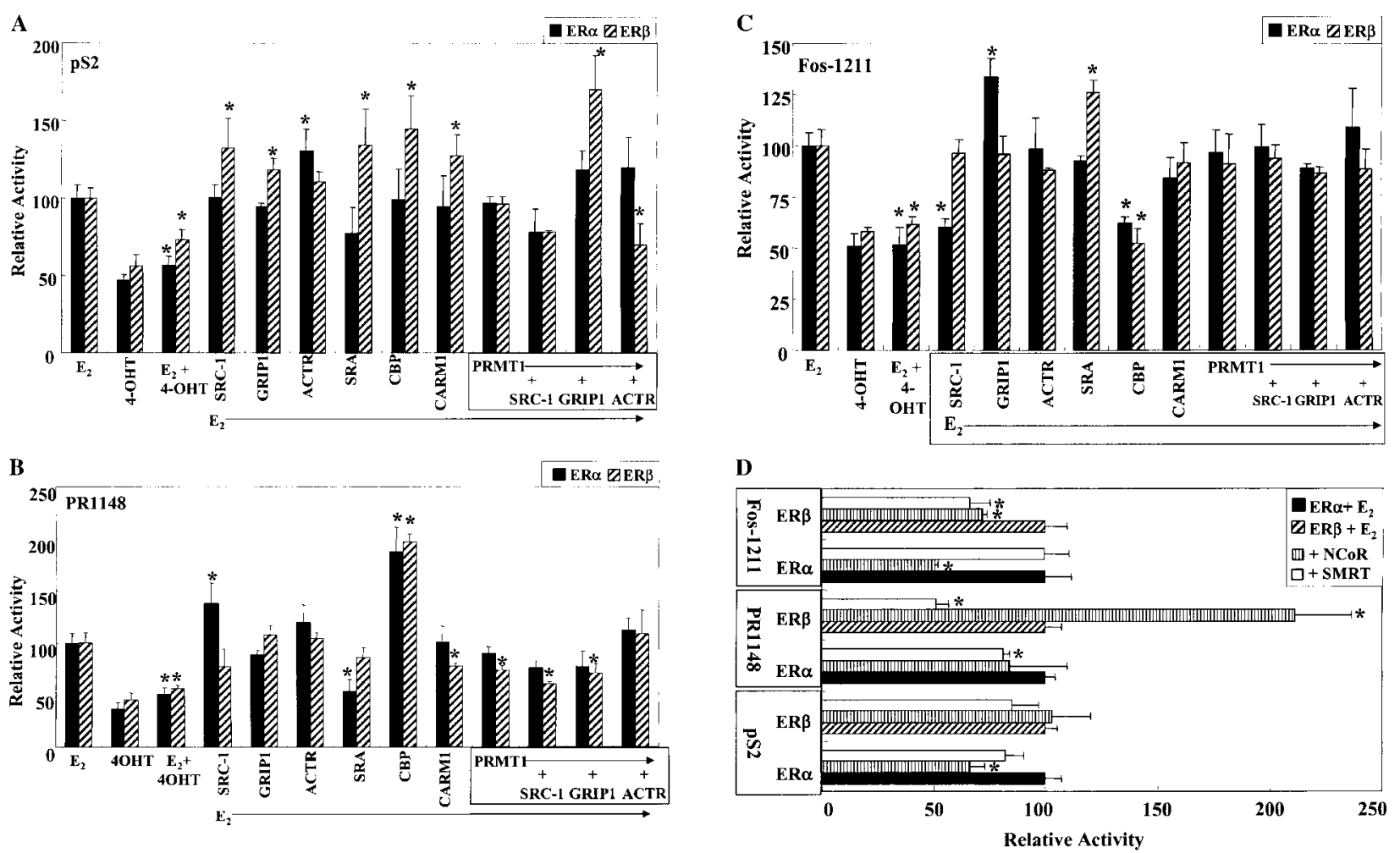

Figure 5 Natural variations on ERE palindrome sequence impact the effect of coactivators and corepressors on $E_{2}$-induced $E R \alpha$ and ER $\beta$ transcription. CHO-K1 cells were transfected with ER $\alpha$ or ER $\beta$ and (A) pS2, (B) PR1148, or (C) Fos-1211 ERE-luciferase reporters plus pRL-CMV and $250 \mathrm{ng}$ of each of the indicated coregulators as described in Materials and methods. (D) The impact of the addition of either NCoR or SMRT on $E_{2}$-induced ER $\alpha$ or $\mathrm{ER} \beta$ activity from the indicated ERE-luciferase reporter. Cells were treated with $10 \mathrm{nM} \mathrm{E}, 100 \mathrm{nM} 4-\mathrm{OHT}$, or both (as indicated) for $30 \mathrm{~h}$ and processed as described in Fig. 1 and in Materials and methods. The maximal activity with $10 \mathrm{nM} \mathrm{E}_{2}$ was set at $100 \%$ and the actual fold-induction values are shown in Fig. $1 \mathrm{~A}$ and $1 \mathrm{~B}$ for $E_{2}-E R \alpha$ and $E R \beta$ respectively. Values are the means \pm S.E.M. of three to nine different experiments. ${ }^{*} P<0.05$, values that are statistically different from the $E_{2}$-induced value for that receptor subtype in the absence of coregulator.

was increased with the addition of GST-ACTR. For ER $\beta$, GST-ACTR increased the total amount of ER $\beta$-bound pS2 complex, but not ER $\beta$-bound EREc38 or EREc13 complexes. This indicated that GST-ACTR shows preferential interaction with $\mathrm{ER} \alpha$ rather than $\mathrm{ER} \beta$ bound to EREc13 and EREc38. Despite a previous report that the GST-SRC-1 and -GRIP1 constructs used here interacted stably with $\mathrm{ER} \alpha$ and $\operatorname{ER} \beta$ in EMSA (Yi et al. 2002), neither formed a complex with $\mathrm{ER} \alpha$ or $\mathrm{ER} \beta$ for any of the tested EREs and had no significant effect on ER-ERE binding (Figs 8C and 9). We concluded that the GRIP1 and SRG-1 RIDs used in the EMSAs do not stably bind ER under our experimental conditions. None of the GST-RIDs supershifted the ER $\alpha$ - or ER $\beta$-Fos1211 or PR1148 complexes (Table 3 and data not shown). Lastly, GST-NCoR RID showed no visible effect on the migration of the ER $\beta$-EREc38 complex (data not shown) and no effect on ER $\beta$-EREc1 3 binding (Fig. 9D).

\section{Discussion}

Lefstin \& Yamamoto (1998) proposed that DNA elements recognized by nuclear transcription factors contain information that is interpreted by the bound regulator. Based on their model, we postulated that DNA acts as an allosteric modulator that, when bound by ER, alters ER conformation, resulting in altered ERE binding affinity and transcriptional activity (Klinge 1999). In turn, ERE-induced changes in ER conformation were 


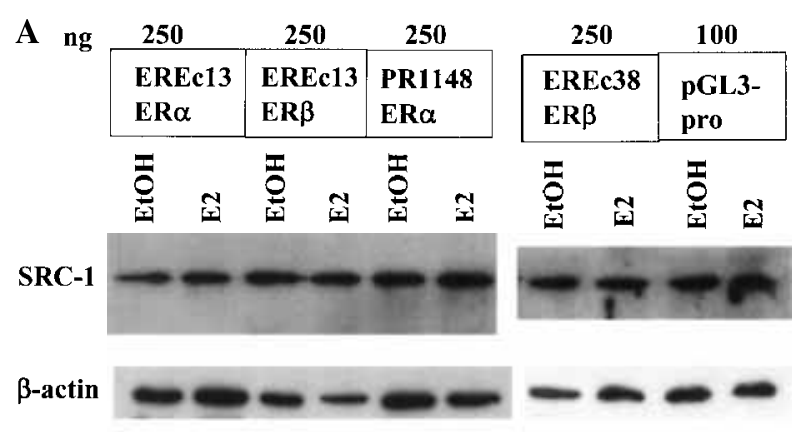

B

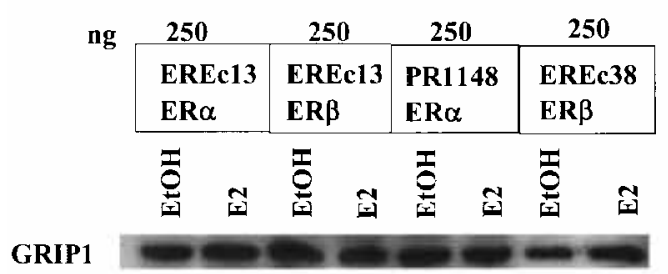

GAPDH

C

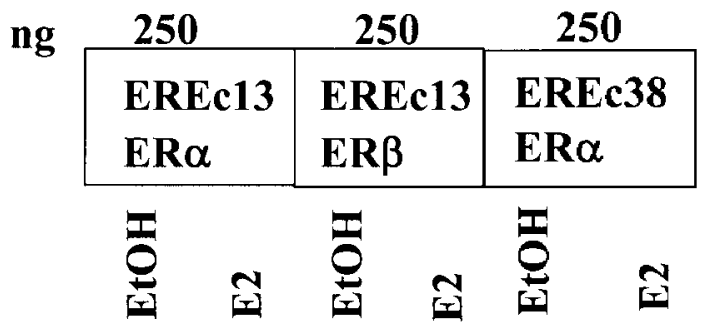

ACTR

\section{$\beta$-actin}

Figure 6 Coactivator expression in transiently transfected $\mathrm{CHO}-\mathrm{K} 1$ cells. $\mathrm{CHO}-\mathrm{K} 1$ cells were transfected with the indicated amount of the expression vector, ER subtype, and ERE. Western blots were performed on cell extracts using antibodies against $(A)$ SRC-1 and $\beta$-actin, (B) GRIP1 and GAPDH, and (C) ACTR and $\beta$-actin. These blots are representative of experiments that were repeated twice.

predicted to alter ER affinity for other 'ligands', such as coactivators or corepressors (Klinge et al. 2001). In fact, we detected conformational differences in ER depending on both ligand and the bound ERE sequence in protease digestion

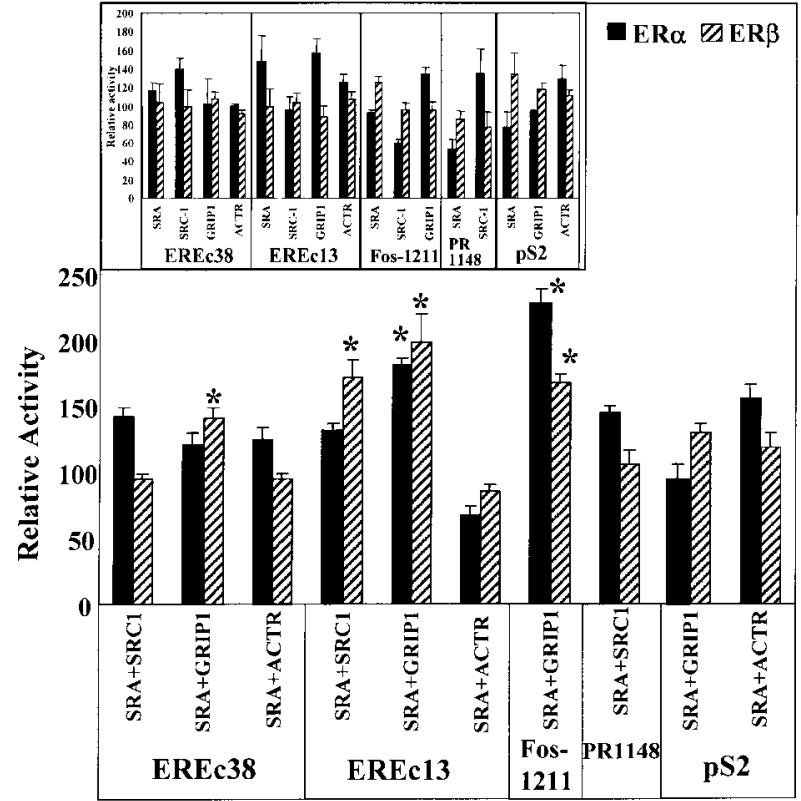

Figure 7 Synergism between SRA and $\mathrm{p} 160$ coregulators depends on ER subtype and ERE sequence. $\mathrm{CHO}-\mathrm{K} 1$ cells were transfected with $\mathrm{ER} \alpha$ or $E R \beta$ and the indicated ERE-luciferase reporters plus PRL-CMV and $250 \mathrm{ng}$ SRA plus each of the indicated p160 coactivators as described in Materials and methods and Fig. 1. The maximal activity with $10 \mathrm{nM} \mathrm{E}_{2}$ was set at 100. Values are the means \pm S.E.M. of three different experiments. ${ }^{\star} P<0.05$, values that are statistically different from both the $E_{2}$-induced value for that receptor subtype/ERE combination with either SRA or the indicated coactivator alone. The inset shows the relative activity of each coactivator alone with $E_{2}-E R \alpha$ or $E_{2}-E R \beta$ on the indicate ERE. These data are taken from Figs 3,4 , and 5 .

experiments (Klinge 1999, Bowers et al. 2000, Tyulmenkov \& Klinge 2000b, 2001a, Tyulmenkov et al. 2000, Klinge et al. 2001, Ramsey \& Klinge 2001). Other protease digestion as well as other in vitro data from the Nardulli (Wood et al. 1998, 2001, Loven et al. 2001a,b), McDonnell (Hall et al. 2002), and Shapiro (Krieg et al. 2004) laboratories have also demonstrated that the ERE sequence and ligand impact $\mathrm{ER} \alpha$ and $\mathrm{ER} \beta$ conformation in vitro. Here we present the first cell-based assay, as a mimic of in vivo conditions, to address how differences in ERE sequence impact the functional interaction of $\operatorname{ER} \alpha$ and $\operatorname{ER} \beta$ with coactivator and corepressor proteins.

To separate the effects of ERE sequence on ER-coactivator interaction from the interaction of that coactivator with other transcription factors in a 
Table 2 GST-RID sequences utilized in the EMSA. These constructs were prepared and used in EMSAs as described in Materials and methods

\section{Amino acid location of RID}

Cointegrator

SRC-1

219-399

GRIP1

623-986

ACTR 522-827

$\mathrm{NCoR}$

2063-2300

\section{Amino acid sequence}

EVMQCFTVSQPKSIQEDGEDFQSCLICIARRLPRPPAITGV ESFMTKQDTTGKIISIDTSSLRAAGRTGWEDLVRKCIYAFF QPQGREPSYARQLFQEVMTRGTASSPSYRFILNDGTMLSA HTKCKLCYPQSPDMQPFIMGIHIIDREHSGLSPQDDTNSG MSIPRVNPSVNPSISPAH

VSSERADGQSRLHDSKGQTKLLQLLTTKSDQMEPSPLAS SLSDTNKDSTGSLPGSGSTHGTSLKEKHKILHRLLQDSSS PVDLAKLTAEATGKDLSQESSSTAPGSEVTIKQEPVSPKK KENALLRYLLDKDDTKDIGLPEITPKLERLDSKTDPASNT KLIAMKTEKEEMSFEPGDQPGSELDNLEEILDDLQNSQLP QLFPDTRPGAPAGSVDKQAIINDLMQLTAENSPVTPVGA QKTALRISQSTFNNPRPGQLGRLLPNQNLPLDITLQSPTGA GPFPPIRNSSPYSVIPQPGMMGNQGMIGNQGNLGNSSTG MIGNSASRPTMPSGEWAPQSSAVRVTCAATTSAMNRPVQ GGMIRNPAA

SLSALQAISEGVGTSLLSTLSSPGPKLDNSPNMNITQPSKV SNQDSKSPLGFYCDQNPVESSMCQSNSRDHLSDKESKESS VEGAENQRGPLESKGHKKLLQLLTCSSDDRGHSSLTNSP LDSSCKESSVSVTSPSGVSSSTSGGVSSTSNMHGSLLQEK HRILHKLLQNGNSPAEVAKITAEATGKDTSSITSCGDGNV VKQEQLSPKKKENNALLRYLLDRDDPSDALSKELQPQVE GVDNKMSQCTSSTIPSSSQEKDPKIKTETSEEGSGDLDNL DAILGDLTSSDFYNNSISSNGSHLGT FARNQVSSQTPQQPPTSTFQNSPSALVSTPVRTKTSNRYSP ESQAQSVHHQRPGSRVSPENLVDKSRGSRPGKSPERSHVS SEPYEPISPPQVPVVHEKQDSLLLLSQRGAEPAEQRNDAR SPGSISYLPSFFTKLENTSPMVKSKKQEIFRKLNSSGGGDS DMAAAQPGTEIFNLPAVTTSGSVSSRGHSFADPASNLGLE DIIRKALMGSFDDKVEDHGVVMSQPMGVVPGTANTS complex promoter, we used a simple model system in which each ERE, plus a relatively short stretch (6-20 bp) of nucleotides identical to those flanking that ERE in the natural human genes for pS2, c-Fos, and PR, was inserted in the same location in the multicloning region of a luciferase reporter gene. This obviates difficulties in data interpretation due to different distances between the ERE and transcription start site (Sathya et al. 1997, Nordeen et al. 1998) and focuses our study on the role of the ERE along with its natural flanking sequence in ER-coregulator interaction. Importantly, we evaluated ER-coregulator activity at a single copy of each ERE rather than multiple tandem copies of the vit A2 ERE. By using CHO-K1 cells that do not express $\mathrm{ER} \alpha$ or $\mathrm{ER} \beta$ (McInerney et al. 1996), we separated effects of coactivators and EREs on ER $\alpha$ versus $\mathrm{ER} \beta$. The importance of our study is that it is the first to examine ER $\beta$-ERE interactions in a functional assay in direct comparison with $\mathrm{ER} \alpha$ activity on the same single copy EREs in the context of their natural flanking sequence.

Our experiments have demonstrated that the sequence of the ERE impacts the functional interaction of $\mathrm{ER} \alpha$ and $\mathrm{ER} \beta$ with coactivators SRC-1, GRIP1, ACTR, CBP, and SRA, the coregulators CARM1 and PRMT1, and corepressors SMRT and NCoR in transiently transfected CHO-K1 cells. Notably, unliganded ER interacts with coregulators in an ERE sequence-dependent manner. Similar findings for CBP and SRC-1 were recently reported by others (Dutertre \& Smith 2003). A brief summary model highlighting some of the ERE-specific differences between unliganded and $\mathrm{E}_{2}$-occupied $\mathrm{ER}$ interaction with coregulators detected in our experiments is presented in Fig. 10. Although the affinity of $\mathrm{ER} \alpha$ or $\operatorname{ER} \beta$ binding to an 
ERE correlates with $\mathrm{E}_{2}$-induced transcriptional activity (Klinge 2001), there is not a correlation between ERE occupancy $\left(K_{\mathrm{d}}\right)$ and the transcriptional response to the tested coactivators, coregulators, and corepressors in transfected CHO-K1 cells. Thus, the effects of coregulatory proteins on $\mathrm{E}_{2}$-activated transcription is not governed solely by the affinity of ER-ERE interaction, but we suggest reflects ERE-mediated alterations in ER conformation (Klinge et al. 2001, Ramsey \& Klinge 2001, Yi et al. 2002) that we propose impact ER-coactivator interaction. Hence, although we are unable to compose a simple rule or set of rules that will predict how an ERE sequence impacts ER-coactivator interaction in transfected cells, our data clearly demonstrated that variations within the core ERE sequence regulate coactivator interaction with liganded ER. An important difference between our study and most previous studies (reviewed in Klinge 2003) is that we subtracted the effect of each coregulator on the ligand-independent (basal) activity of $\mathrm{ER} \alpha$ or $\mathrm{ER} \beta$ for each ERE. Thus, the findings in Table 1 summarize how coregulators impact $\mathrm{E}_{2}$-dependent $\mathrm{ER} \alpha$ and $\mathrm{ER} \beta$ transcriptional activity from different EREs. We suggest that small changes with individual coactivators may be physiologically significant when combined with the other coregulators in the cell. For example, a 50-100\% increase in transcription of the transcription factors Fos or PR could effectively double the amount of Fos and PR proteins. Doubling PR expression subsequently could have a synergistic effect on downstream gene targets.

Our results have shown that the length of the ERE palindrome differentially impacts coactivator activity for $\mathrm{ER} \alpha$ and $\mathrm{ER} \beta$. Of the EREs examined in this study, EREc38 has the longest (17 bp) perfectly palindromic ERE, binds ER $\alpha$ and ER $\beta$ with highest affinity (Table 1), gives the highest $\mathrm{E}_{2}$-induced transcription (Fig. 1), and shows the least effect of coactivators on $\mathrm{E}_{2}$-induced $\mathrm{ER} \alpha$ or ER $\beta$ activity. SRC- 1 was the only coactivator that stimulated $\mathrm{E}_{2}$-induced $\mathrm{ER} \alpha$ but not $\mathrm{ER} \beta$ transcription from EREc38. In contrast, SRG-1 had no effect on $\mathrm{E}_{2}$-ER $\alpha$ activity on EREc13. Hence, the length of the ERE palindrome and the presence of the conserved 5' AT-rich region found in the vit A2 gene appear to enhance ER $\alpha$-SRC-1 functional interaction in this transient transfection assay.

The pS2 ERE showed the most liganddependent ER responsiveness to the coactivators tested. Based on a report showing low interaction of ER $\alpha$-pS2 with SRC-1 and ACTR-RID peptides in vitro (Hall et al. 2002), we predicted that SRC-1 and ACTR would have minimal impact on $\mathrm{E}_{2}$-ER $\alpha$ activity on the $\mathrm{pS} 2-\mathrm{ERE}$ reporter. Indeed, SRG-1 enhanced $\mathrm{E}_{2}$-ER $\beta$, but not ER $\alpha$ transcription from the pS2-ERE. On the other hand, ACTR stimulated $\mathrm{E}_{2}$-ER $\alpha$, but not ER $\beta$ transcription from the pS2 ERE, despite the interaction of GST-ACTR with both ER $\alpha$ and ER $\beta$ bound to the pS2 ERE in vitro (Fig. 8). This difference from the aforementioned predication (Hall et al. 2002) suggests that amino acids in addition to the RID in ACTR impact transactivation by ER $\alpha$. This suggestion agrees with data showing that the three NR boxes from SRC-1, GRIP1, and ACTR have different affinities for $\mathrm{E}_{2}$-occupied $\mathrm{ER} \alpha$ and $\mathrm{ER} \beta$ in vitro (Wong et al. 2001). Our cotransfection data are also in agreement with the observation that less GRIP1 was retained by $\mathrm{ER} \alpha$ bound to the $\mathrm{pS} 2$ ERE versus the vit A2 ERE in vitro (Wood et al. 2001).

As anticipated from the discussion above, data from our EMSA experiments using GST-RIDs did not fully correlate with results from the transient transfection assays. These divergent results are most likely due to the use of a single RID domain in the EMSA experiments and the use of full-length proteins in the transient transfection assays. Our EMSA data are in agreement with time-resolved fluorescence resonance energy transfer (FRET) experiments showing no interaction between ER $\alpha$ and the first RID of SRC-1 and minimal recruitment to $\mathrm{ER} \beta$ in vitro (Bramlett et al. 2001). Similarly, our EMSAs and the FRET studies (Bramlett et al. 2001) indicate that the first RID of ACTR interacts with both ER $\alpha$ and ER $\beta$. Further experiments are necessary to determine how full-length coactivators influence ER-ERE binding affinity.

Results from scintillation proximity and mammalian two-hybrid assays showed that the ligand binding domain (LBD) of $\operatorname{ER} \beta$ interacts with the RIDs of pl60 coactivators in the following order of affinity (high-low): GRIP1 $>$ ACTR $>$ SRG$1>>>$ p300/CBP (Northrop et al. 2000). These data suggest that $\mathrm{E}_{2}-\mathrm{ER} \beta$ transcription would be expected to be stimulated most by GRIP1, less by ACTR and SRC-1, and the least with CBP. On the other hand, intact ER $\beta$ interacted with comparable affinity with the immobilized NR boxes of SRC-1, 
A
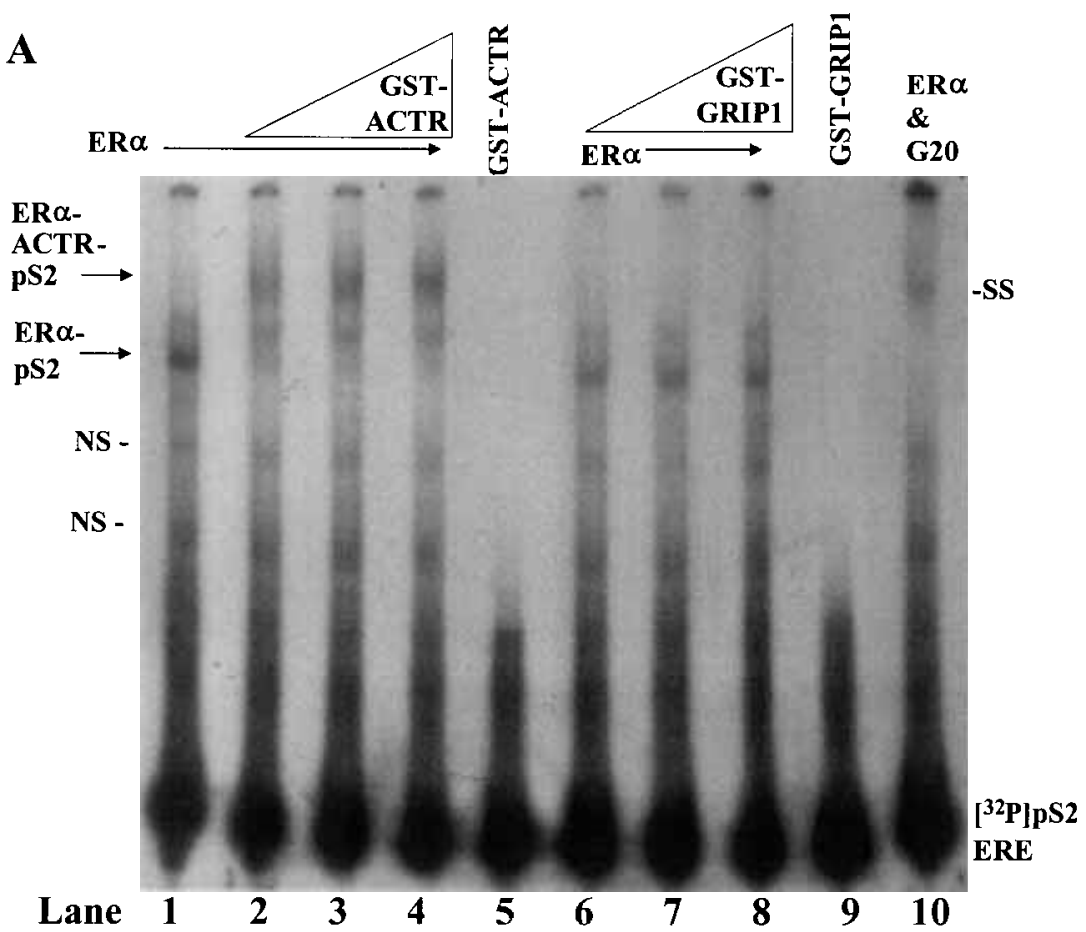

B
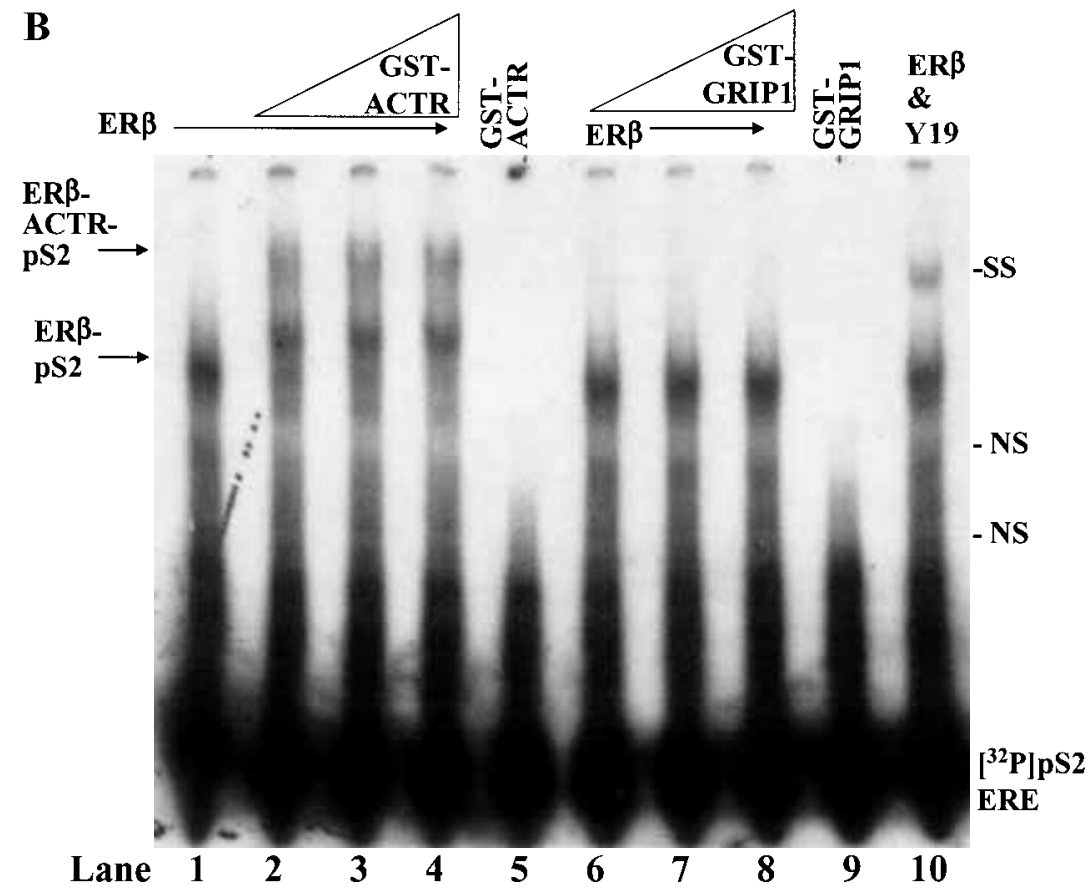
C

ER $\alpha$-pS2-ERE binding

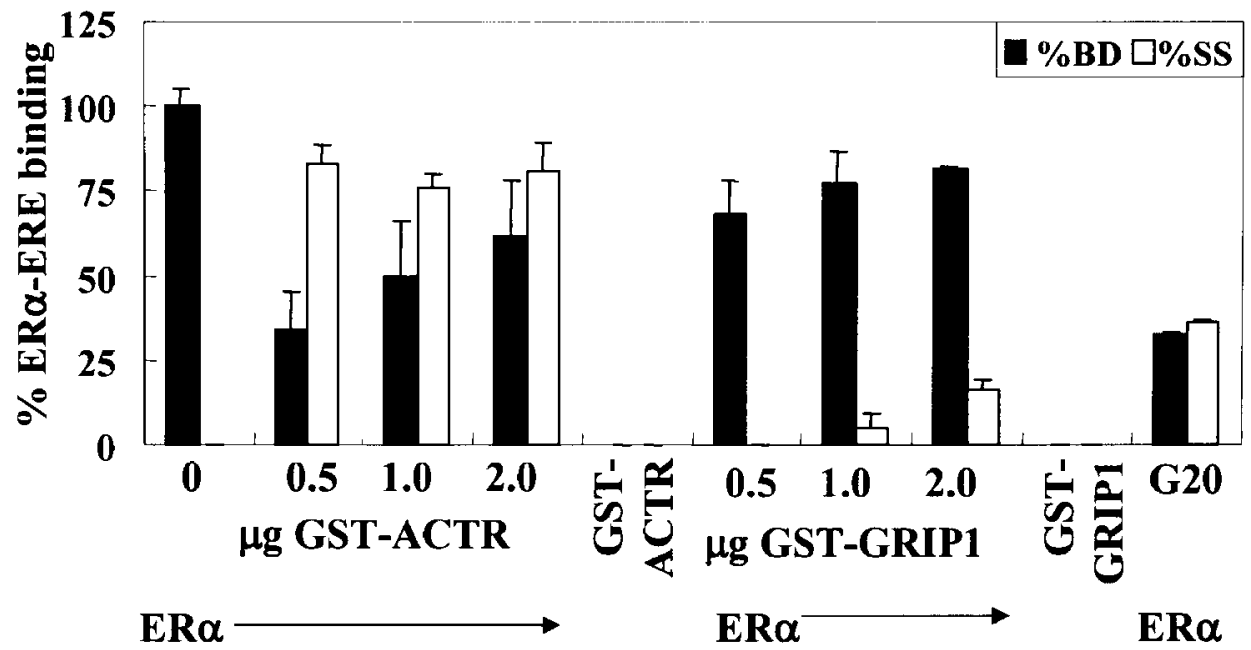

D

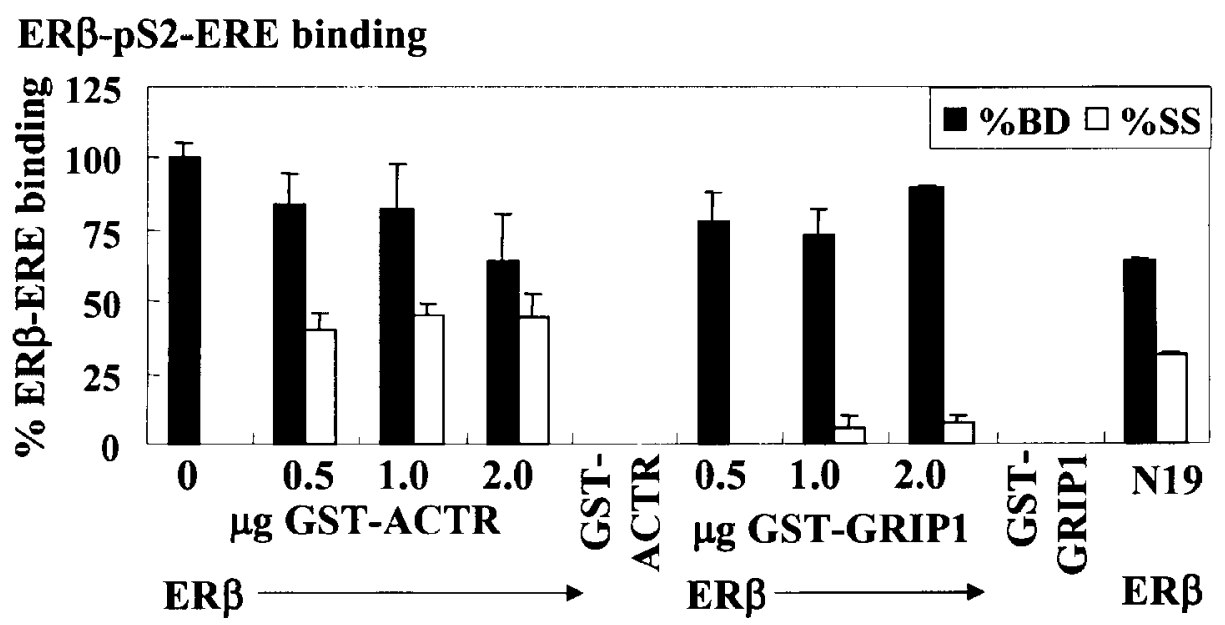

Figure 8 The RID of ACTR, but not GRIP1, interacts with ER $\alpha$ and ER $\beta$ bound to the $p S 2$ ERE in vitro. (A) Human ER $\alpha$ was incubated with [ $\left.{ }^{32} \mathrm{P}\right] \mathrm{pS} 2-\mathrm{ERE}$ as described in Materials and methods. GST-ACTR or GST-GRIP1 $(0.5,1$, or $2 \mu \mathrm{g})$ were added to ER $\alpha$ and [32P]pS2-ERE in lanes 2-4 and 6-7 respectively, as indicated. GST-ACTR and GST-GRIP alone did not bind pS2-ERE (lanes 5 and 9). Lane 10 included $1 \mu$ ER $\alpha$-specific antibody G20. (B) Rat ER $\beta$ was incubated with [ $\left.{ }^{32} \mathrm{P}\right] \mathrm{pS} 2-\mathrm{ERE}$ as described in Materials and methods. GST-ACTR or GST-GRIP1 $(0.5,1$, or $2 \mu \mathrm{g})$ were added to ER $\beta$ and [ $\left.{ }^{32} \mathrm{P}\right] \mathrm{pS} 2-$ ERE in lanes 2-4 and 6-7 respectively, as indicated. GST-ACTR and GST-GRIP alone did not bind pS2-ERE (lanes 5 and 9). Lane 10 included $1 \mu$ I ER $\beta$-specific antibody Y-19. NS indicates non-specific binding of baculovirus proteins to the ERE; SS indicates the supershifted complex formed between the ER antibody and the ER-pS2 complex. This autoradiograph is representative of two independent EMSA experiments for both ER $\alpha$ and ER $\beta$ showing similar results. (C and D) EMSA data were quantitated as described in Materials and methods. Values are the \% of (C) ER $\alpha$ or (D) ER $\beta$ binding in the absence of added coregulator or antibody. \%BD=ER-ERE bound; \%SS=ER-ERE supershifted with the added GST fusion protein or antibody. Values are the average of two separate experiments \pm S.D. 

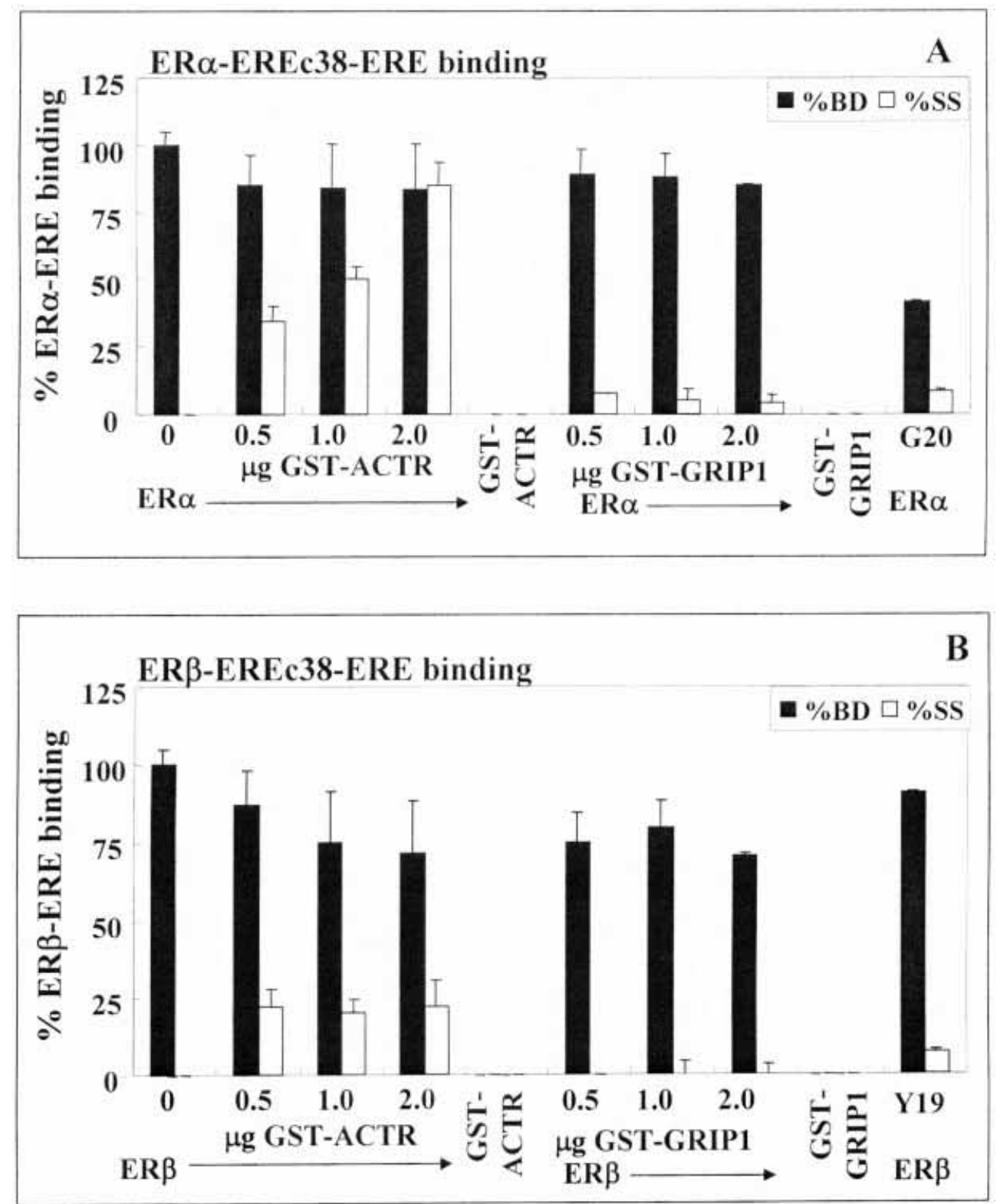

GRIP1, and ACTR in vitro (Wong et al. 2001). Hence, the length of the ER $\beta$ used influences coactivator interaction in vitro. In contrast to these in vitro results, we observed that GRIP1 stimulated $\mathrm{E}_{2}$-ER $\beta$ transcription only from the $\mathrm{pS} 2 \mathrm{ERE}$. One possible explanation of these results is that GRIP1 requires a cellular cofactor(s) for the other EREs that is not expressed in CHO-K1 cells. However, GRIP1 did not enhance $\mathrm{E}_{2}$-ER $\beta$ activity on either EREc38 or pS2-ERE in HEG-1A human endometrial cancer cells (C M Klinge, unpublished data), indicating that $\mathrm{CHO}-\mathrm{K} 1$ are not unique in this response. Cells that express endogenous ER $\beta$ should be tested to further evaluate the impact of GRIP1 on ER $\beta$ activity.

$\mathrm{ER} \alpha$ interacts functionally with p300 and CBP (Shibata et al. 1997) which are 'cointegrators' because they form complexes with TBP and a variety of activator proteins (McKenna et al. 1999). CBP stimulated unliganded $\mathrm{ER} \alpha$ and $\mathrm{ER} \beta$ transcription at all EREs except PR1148. The finding that CBP enhanced $\mathrm{E}_{2}-\mathrm{ER} \alpha$ transcription only from the 

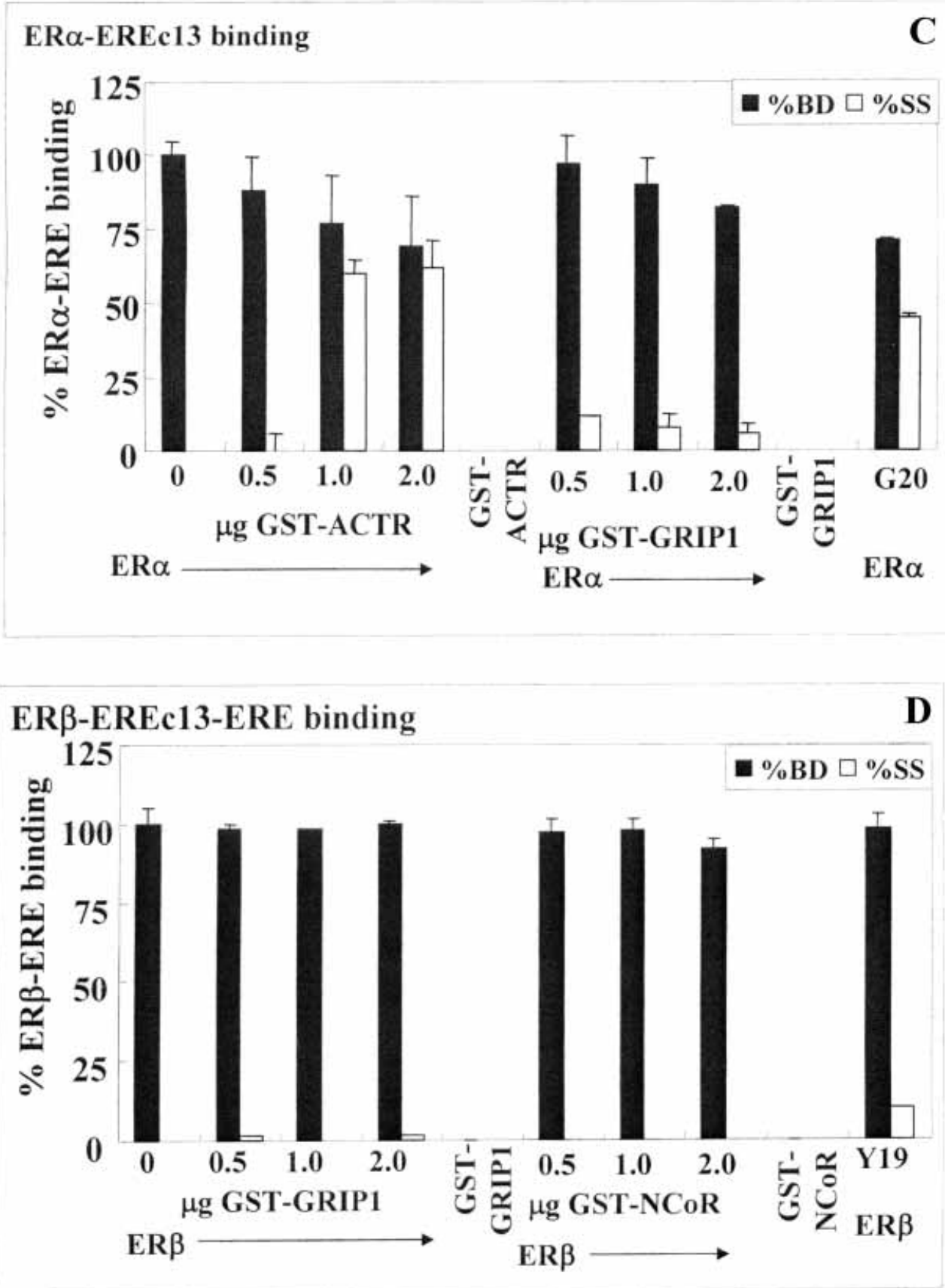

Figure 9 Effect of GST-coregulators on ER-ERE binding in vitro. EMSA data were quantitated as described in Materials and methods. Values are the \% of (A and $C) E R \alpha$ or ( $B$ and $D)$ ER $\beta$ binding to $(A$ and $B)$ EREc38 or $(C$ and $D)$ EREc13 in the absence of added coregulator or antibody. \%BD=ER-ERE bound; \%SS=ER-ERE supershifted with the added GST fusion protein or antibody. Values are the average of two to three separate experiments \pm S.E.M. 
Table 3 Comparison of the effect of the indicated coregulator on the transcriptional activity $E_{2}-E R \alpha$ or $-E R \beta$ with the effect of the GST-RID of that coregulator on ER $\alpha$ or ER $\beta$ interaction with that of ERE in vitro in EMSA. Data are the summary of transient transfection assays shown in Figs 3-5 and three separate EMSA gels, examples of which are shown in Fig. 8, for each combination of ER-ERE and GST-RID

\section{$E_{2}-E R \alpha$ transcriptional activity}

ERE sequence EREc38

SRC-1 (stimulation) GRIP1 or ACTR (no effect)

\section{EMSA E $E_{2}$-ER $\alpha$}

No effect of SRC-1 or GRIP1*; ACTR supershifted the ER $\alpha$-EREc38 complex

$E_{2}$-ER $\beta$
transcriptional
activity

No effect of SRC-1 or GRIP1; ACTR $^{*}$ supershifted the ER $\alpha$-EREc13 complex No effect of GRIP1*; ACTR $^{*}$ supershifted the ER $\alpha$-pS2-ERE complex

No effect of SRC1 or GRIP1*

No effect of SRC-1* or GRIP1
GRIP1 (no effect) NCoR (stimulation)

GRIP1 (no effect) NCoR (inhibition)
EMSA $E_{2}$-ER $\beta$

No effect of SCR $-1^{*}$ or GRIP1*; ACTR supershifted the ER $\beta$ EREc38 complex; no effect of $\mathrm{NCoR}$ No effect of GRIP1* or $\mathrm{NCoR}$ No effect of GRIP1; ACTR supershifted the ER $\beta$-pS2ERE complex No effect of GRIP1* or $\mathrm{NCoR}$ No effect of GRIP1 or NCoR

${ }^{*}$ Agreement between transient transfection and EMSA results.

PR1148 ERE is consistent with experiments showing that CBP shows weaker interaction with the $\mathrm{ER} \alpha \mathrm{LBD}$ than SRG-1 in vitro (Heery et al. 2001). In contrast to our ER $\alpha$ findings, $\mathrm{CBP}$ enhanced $\mathrm{E}_{2}$ ER $\beta$ transcription from pS2 and PR1148 EREs (Table 1). Ours is the first examination of the impact of CBP on ligand-dependent ER $\beta$-induced transcription. We conclude that $\mathrm{CBP}$ interacts differently with $\operatorname{ER} \alpha$ and $\operatorname{ER} \beta$ and that the ERE sequence impacts this interaction.

SRA is a unique ER coactivator because it functions as an RNA molecule in vivo and it enhances ER $\alpha$ transactivation through AF-1 (Lanz et al. 1999). Ours is the first study to compare the activity of SRA with $\mathrm{ER} \alpha$ and $\mathrm{ER} \beta$ on natural EREs. Although a recent study reported that SRA enhanced the activities of $\mathrm{E}_{2}-\mathrm{ER} \alpha$ and $-\mathrm{ER} \beta$ on a two-tandem vit A2 ERE-luciferase reporter in COS-1 or HEK-293 cells without affecting basal activity (Deblois \& Giguere 2003), we observed that SRA stimulated basal, unliganded ER $\alpha$ and ER $\beta$ activity on all EREs with the exception of $\operatorname{ER} \beta$ on the pS2 ERE. SRA showed the greatest activity with unliganded ER $\alpha$ and ER $\beta$ on the Fos-1211 ERE. This finding warrants further investigation in future studies. Data showing that SRA interacts with p72 and p68 coactivators, which bind GRIP1 but do not interact with or activate $\operatorname{ER} \beta$ (Watanabe et al. 2001), imply that SRA may not stimulate $\operatorname{ER} \beta$ transcription. Our data are in agreement with this prediction: SRA did not enhance $\mathrm{E}_{2}$-ER $\beta$ transcription with the exception of the pS2 ERE, indicating that the ERE sequence impacts SRA-ER $\beta$ interaction. Since SRA forms a complex with SRC-1 (Lanz et al. 1999), we evaluated the combined effect of the pl60 coactivators and SRA on $\mathrm{E}_{2}$-induced $\mathrm{ER} \alpha$ and $\operatorname{ER} \beta$ activity on different EREs. Our results indicated that 

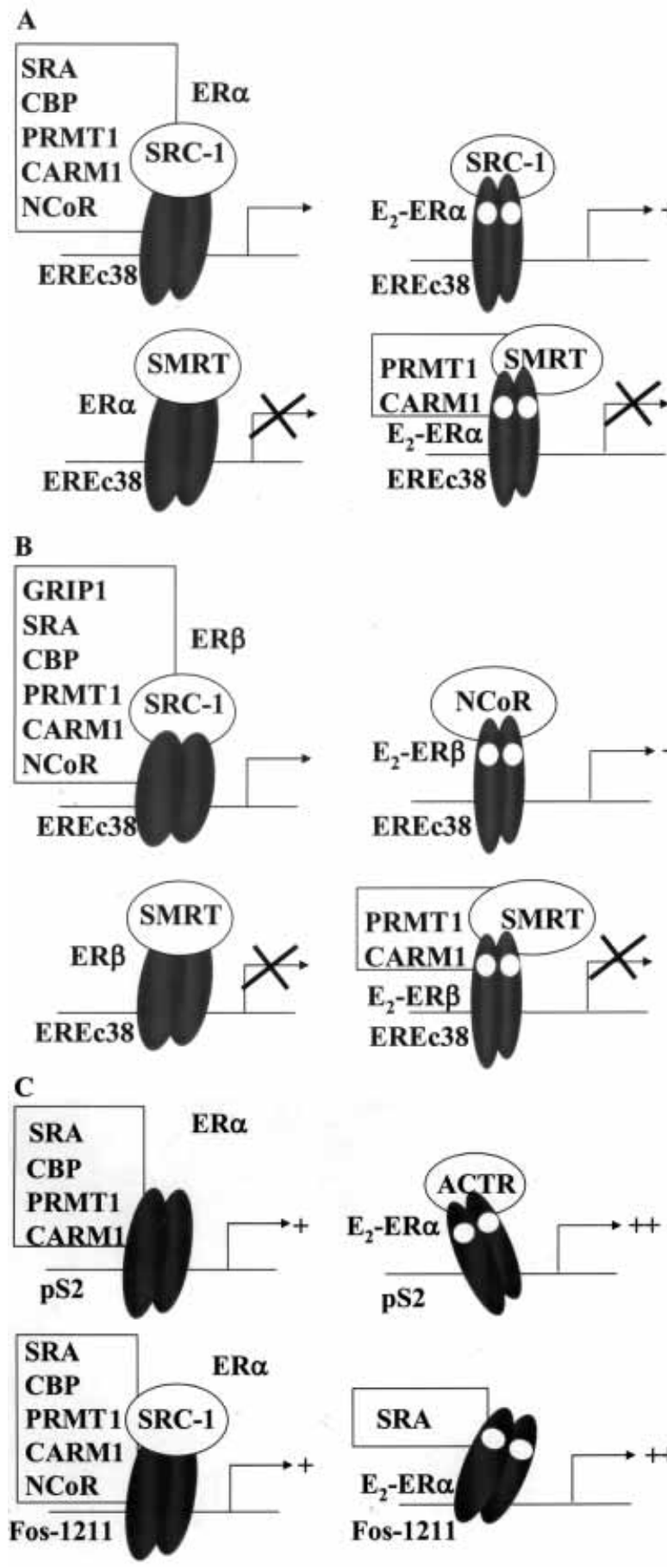

Figure 10 Model for ERE sequence-, ER subtype-, coregulator- and ligand state-dependent transcription by ER. Coactivators and corepressors regulate ER $\alpha$ and ER $\beta$ transcriptional activity depending on different conformations of the receptors in their unliganded versus $E_{2}$-occupied as they bind to EREs from different genes. Please see Discussion for further details. both ER subtype and DNA sequence impact SRA activity.

CARM1 and PRMT1 interact with p160 family coactivators and stimulate NR transcription (Chen et al. 2000, Koh et al. 2001). PRMT1 stimulated unliganded $\mathrm{ER} \alpha$ and $\mathrm{ER} \beta$ activity on all EREs. CARM1 differed from PRMT1 in that it did not stimulate unliganded $\operatorname{ER} \alpha$ and $\operatorname{ER} \beta$ on the PR1148 and Fos-1211 EREs. The only $\mathrm{E}_{2}$ dependent stimulatory activity of CARMl was with $\mathrm{E}_{2}-\mathrm{ER} \beta$ on the $\mathrm{pS} 2$ ERE. It will be important to determine if the ERE sequence impacts the methyltransferase activity of PRMT1 and CARM1.

In GST pull-down assays, corepressors NGoR and SMRT interact with $\mathrm{ER} \alpha$ in a ligandindependent manner (Smith et al. 1997, Lavinsky et al. 1998). Chromatin immunoprecipitation experiments revealed that NGoR interacts with $\mathrm{ER} \alpha$ in the promoters of the c-Myc and cathepsin $\mathrm{D}$ genes in MCF-7 breast cancer cells treated with tamoxifen or raloxifene (Shang \& Brown 2002), indicating that these corepressors play a role in transcriptional silencing. Here we noted that NCoR increased unliganded $\operatorname{ER} \alpha$ and $\operatorname{ER} \beta$ activity from all but the pS2 and PR1148 EREs. Differences between native chromatin and partial chromatin structure on transfected reporter constructs may be responsible for this difference. The mechanism of stimulation of ER basal activity by NGoR is unclear; however, NGoR and SMRT interacted directly with ACTR, SRC-1, and GRIP1 in vitro and in transfected cells ( $\mathrm{Li}$ et al. 2002). Further, NCoR enhanced unliganded TR $\beta$-ACTR interaction (Li et al. 2002). Whether NCoR facilitates ER-endogenous ACTR interaction in the absence of ligand is unknown. Further studies are needed to address the role of NCoR in fine-tuning transcriptional repression versus activation by $\mathrm{ER} \alpha$ and $\mathrm{ER} \beta$.

In mammalian two-hybrid assays, NCoR had no effect on $\mathrm{E}_{2}$-activated $\mathrm{ER} \alpha$ or $\mathrm{ER} \beta$ reporter expression (Zhang et al. 2000). In contrast, NGoR inhibited $\mathrm{E}_{2}$-induced $\mathrm{ER} \alpha$ transcription only from the pS2 and Fos-1211 EREs in our cell-based assays. Therefore, the ERE sequence impacts NCoR-mediated transcriptional repression from a transfected plasmid. SMRT reduced basal and 4-OHT-stimulated reporter gene activity in HepG2 cells transfected with $\mathrm{ER} \alpha$, but had no effect on $\mathrm{E}_{2}$-activated reporter activity (Smith et al. 1997). 
Similarly, we found that SMRT inhibited basal transcription by ER $\alpha$ or ER $\beta$, but SMRT inhibited $\mathrm{E}_{2}$-induced transcription for both $\operatorname{ER} \alpha$ and $\operatorname{ER} \beta$, although the effect was more pronounced for ER $\alpha$ than ER $\beta$. Notably, NGoR enhanced 4-OHT inhibition of $\mathrm{ER} \alpha$ activity, but not $\mathrm{ER} \beta$ activity whereas SMRT increased 4-OHT inhibition of $\mathrm{ER} \beta$, not $\mathrm{ER} \alpha$.

In summary, the data presented here have demonstrated for the first time that the nucleotide sequence of the ERE and its immediate flanking sequences from the native gene differentially impact $\operatorname{ER} \alpha$ and $\operatorname{ER} \beta$ transcription and the functional interaction of coregulatory proteins in transfected cells. In agreement with previous investigators we conclude that the ERE nucleotide sequence impacts physical (Wood et al. 1998, 2001, Loven et al. 2001a, Hall et al. 2002) and functional interaction of $\operatorname{ER} \alpha$ and $\operatorname{ER} \beta$ with coregulators. These data are in agreement with our previous studies and those of other investigators showing that DNA is an allosteric modulator of ER action (reviewed in Klinge 2003). This allows gene-specific recruitment of coregulators to $\operatorname{ER} \alpha$ and $\operatorname{ER} \beta$ which, along with cell-specific ratios of coregulator expression, results in tissue-specific gene transcriptional responses to $\mathrm{E}_{2}$ in vivo.

\section{Acknowledgements}

This work was supported by NIH R01 DK 53220 and a University of Louisville School of Medicine Research Grant to G M K. S C J was supported by NIH Grant T35 GM08561. We thank Drs Milan Bagchi, Margarita Hadzopoulou-Cladaras, Jan-Ake Gustafsson, Russell Hilf, Anthony Hollenberg, Benita Katzenellenbogen, Bert W O'Malley, Mesut Muylan, Brian Rowan, and Michael Stallcup for providing their constructs for our experiments. We thank Drs Barbara J Clark and Rhona Feltzer for their insightful comments on this manuscript.

\section{References}

Bowers JL, Tyulmenkov VV, Jernigan SC \& Klinge CM 2000 Resveratrol acts as a mixed agonist/antagonist for estrogen receptors alpha and beta. Endocrinology $1413657-3667$.

Bramlett KS, Wu Y \& Burris TP 2001 Ligands specify coactivator nuclear receptor (NR) box affinity for estrogen receptor subtypes. Molecular Endocrinology 15 909-922.
Chen D, Huang SM \& Stallcup MR 2000 Synergistic, p160 coactivator-dependent enhancement of estrogen receptor function by CARM1 and p300. Fournal of Biological Chemistry 275 40810-40816.

Cohen RN, Putney A, Wondisford FE \& Hollenberg AN 2000 The nuclear corepressors recognize distinct nuclear receptor complexes. Molecular Endocrinology 14 900-914.

Coleman KM, Dutertre M, El-Gharbawy A, Rowan BG, Weigel NL \& Smith CL 2003 Mechanistic differences in the activation of estrogen receptor-alpha (ERalpha )- and ERbeta-dependent gene expression by cAMP signaling pathway(s). Fournal of Biological Chemistry 278 12834-12845.

Couse JF \& Korach KS 1999 Estrogen receptor null mice: what have we learned and where will they lead us? Endocrine Reviews 20 358-417.

Deblois G \& Giguere V 2003 Ligand-independent coactivation of ERalpha AF-1 by steroid receptor RNA activator (SRA) via MAPK activation. Fournal of Steroid Biochemistry and Molecular Biology 85 123-131.

Delage-Mourroux R, Martini PG, Choi I, Kraichely DM, Hoeksema J \& Katzenellenbogen BS 2000 Analysis of estrogen receptor interaction with a repressor of estrogen receptor activity (REA) and the regulation of estrogen receptor transcriptional activity by REA. Fournal of Biological Chemistry $\mathbf{2 7 5}$ 35848-35856.

Dell H \& Hadzopoulou-Cladaras M 1999 CREB-binding protein is a transcriptional coactivator for hepatocyte nuclear factor-4 and enhances apolipoprotein gene expression. Fournal of Biological Chemistry 274 9013-9021.

Driscoll MD, Sathya G, Muyan M, Klinge CM, Hilf R \& Bambara RA 1998 Sequence requirements for estrogen receptor binding to estrogen response elements. Fournal of Biological Chemistry 273 29321-29330.

Dutertre M \& Smith CL 2003 Ligand-independent interactions of p160/steroid receptor coactivators and CREB-binding protein $(\mathrm{CBP})$ with estrogen receptor- $\alpha$ : regulation by phosphorylation sites in the A/B region depends on other receptor domains. Molecular Endocrinology 17 1296-1314.

Hager GL, Smith CL, Fragoso G, Wolford R, Walker D, Barsony J \& Htun H 1998 Intranuclear trafficking and gene targeting by members of the steroid/nuclear receptor superfamily. Fournal of Steroid Biochemistry and Molecular Biology 65 125-132.

Hall JM, Chang CY \& McDonnell DP 2000 Development of peptide antagonists that target estrogen receptor beta-coactivator interactions. Molecular Endocrinology 14 2010-2023.

Hall JM, McDonnell DP \& Korach KS 2002 Allosteric regulation of estrogen receptor structure, function, and coactivator recruitment by different estrogen response elements. Molecular Endocrinology 16 469-486.

Hebbar PB \& Archer TK 2003 Chromatin remodeling by nuclear receptors. Chromosoma $\mathbf{1 1 1} 495-504$.

Heery DM, Hoare S, Hussain S, Parker MG \& Sheppard H 2001 Core LXXLL motif sequences in CREB-binding protein, SRC1, and RIP140 define affinity and selectivity for steroid and retinoid receptors. Fournal of Biological Chemistry 276 6695-6702.

Jiang W, Nordeen SK \& Kadonaga JT 2000 Transcriptional analysis of chromatin assembled with purified ACF and dNAP1 reveals that acetyl-CoA is required for preinitiation complex assembly. Fournal of Biological Chemistry 275 39819-39822.

Klein-Hitpass L, Ryffel GU, Heitlinger E \& Cato AC 1988 A 13 bp palindrome is a functional estrogen responsive element and interacts specifically with estrogen receptor. Nucleic Acids Research 16 647-663.

Klinge CM 1999 Estrogen receptor binding to estrogen response elements slows ligand dissociation and synergistically activates 
reporter gene expression. Molecular and Cellular Endocrinology 150 99-111.

Klinge CM 2000 Estrogen receptor interaction with co-activators and co-repressors. Steroids 65 227-251.

Klinge CM 2001 Estrogen receptor interaction with estrogen response elements. Nucleic Acids Research 29 2905-2919.

Klinge CM 2003 Estrogen response element sequence as an allosteric regulator of estrogen receptor action. CHEMTRACTS Biochemistry and Molecular Biology 16 1-18.

Klinge CM, Peale FV Jr, Hilf R, Bambara RA \& Zain S 1992 Cooperative estrogen receptor interaction with consensus or variant estrogen responsive elements in vitro. Cancer $\mathbf{5 2}$ 1073-1081.

Klinge CM, Silver BF, Driscoll MD, Sathya G, Bambara RA \& Hilf R 1997 COUP-TF interacts with estrogen receptor, binds to estrogen response elements and half-sites, and modulates estrogen-induced gene expression. Fournal of Biological Chemistry 272 31465-31474.

Klinge CM, Bowers JL, Kulakosky PC, Kamboj KK \& Swanson HI 1999 The aryl hydrocarbon receptor (AHR)/AHR nuclear translocator (ARNT) heterodimer interacts with naturally occurring estrogen response elements. Molecular and Cellular Endocrinology 157 105-119.

Klinge CM, Kaur K \& Swanson HI 2000 The aryl hydrocarbon receptor interacts with estrogen receptor alpha and orphan receptors COUP-TFI and ERR $\alpha 1$. Archives of Biochemistry and Biophysics 373 163-174.

Klinge CM, Jernigan SC, Smith SL, Tyulmenkov VV \& Kulakosky PC 2001 Estrogen response element sequence impacts the conformation and transcriptional activity of estrogen receptor $\alpha$. Molecular and Cellular Endocrinology 174 151-166.

Koh SS, Chen D, Lee YH \& Stallcup MR 2001 Synergistic enhancement of nuclear receptor function by p160 coactivators and two coactivators with protein methyltransferase activities. Fournal of Biological Chemistry 276 1089-1098.

Krieg AJ, Krieg SA, Ahn BS \& Shapiro DJ 2004 Interplay between estrogen response element sequence and ligands controls in vivo binding of estrogen receptor to regulated genes. Fournal of Biological Chemistry 279 5025-5034.

Kuiper GG, Carlsson B, Grandien J, Enmark E, Haggblad J, Nilsson S \& Gustafsson J-A 1997 Comparison of the ligand binding specificity and transcript tissue distribution of estrogen receptors $\alpha$ and $\beta$. Endocrinology 138 863-870.

Kulakosky PC, Jernigan SC, McCarty MA \& Klinge CM 2002 Response element sequence regulates estrogen receptor alpha and beta affinity and activity. Foumal of Molecular Endocrinology 29 $137-152$.

Lanz RB, McKenna NJ, Onate SA, Albrecht U, Wong J, Tsai SY, Tsai MJ \& O’Malley BW 1999 A steroid receptor coactivator, SRA, functions as an RNA and is present in an SRC-1 complex. Cell 97 17-27.

Lavinsky R, Jepsen K, Heinzel T, Torchia J, Mullen TM, Schiff R, Del-Rio AL, Ricote M NS, Gemsch J, Hilsenbeck SG et al. 1998 Diverse signaling pathways modulate nuclear receptor recruitment of N-CoR and SMRT complexes. PNAS 95 2920-2925.

Lee SK, Anzick SL, Choi JE, Bubendorf L, Guan XY, Jung YK, Kallioniemi OP, Kononen J, Trent JM, Azorsa D et al. 1999 A nuclear factor, ASC-2, as a cancer-amplified transcriptional coactivator essential for ligand-dependent transactivation by nuclear receptors in vivo. Fournal of Biological Chemistry 274 34283-34293.

Lefstin JA \& Yamamoto KR 1998 Allosteric effects of DNA on transcriptional regulators. Nature 392 885-888.

Li X, Kimbrel EA, Kenan DJ \& McDonnell DP 2002 Direct interactions between corepressors and coactivators permit the integration of nuclear receptor-mediated repression and activation. Molecular Endocrinology 16 1482-1491.
Loven MA, Likhite VS, Choi I \& Nardulli AM 2001 $a$ Estrogen response elements alter coactivator recruitment through allosteric modulation of estrogen receptor beta conformation. Fournal of Biological Chemistry $27645282-45288$.

Loven MA, Wood JR \& Nardulli AM $2001 b$ Interaction of estrogen receptors alpha and beta with estrogen response elements. Molecular and Cellular Endocrinology 181 151-163.

McInerney EM, Tsai M-J, O’Malley BW \& Katzenellenbogen BS 1996 Analysis of estrogen receptor transcriptional enhancement by a nuclear receptor coactivator. PNAS 93 10069-10073.

McKenna NJ \& O'Malley BW 2002 Minireview: nuclear receptor coactivators - an update. Endocrinology 143 2461-2465.

McKenna NJ, Lanz RB \& O’Malley BW 1999 Nuclear receptor coregulators: cellular and molecular biology. Endocrine Reviewes 20 321-344.

Mak H, Hoare S, Henttu PMS \& Parker MG 1999 Molecular determinants of the estrogen receptor-coactivator interface. Molecular and Cellular Endocrinology 19 3895-3903.

Metivier R, Stark A, Flouriot G, Hubner MR, Brand H, Penot G, Manu D, Denger S, Reid G, Kos M et al. 2002 A dynamic structural model for estrogen receptor-alpha activation by ligands, emphasizing the role of interactions between distant $\mathrm{A}$ and $\mathrm{E}$ domains. Molecular Cell 10 1019-1032.

Nordeen SK, Ogden CA, Taraseviciene L \& Lieberman BA 1998 Extreme position dependence of a canonical hormone response element. Molecular Endocrinology 12 891-898.

Norris JD, Fan D, Stallcup MR \& McDonnell DP 1998 Enhancement of estrogen receptor transcriptional activity by the coactivator GRIP-1 highlights the role of activation function 2 in determining estrogen receptor pharmacology. Fournal of Biological Chemistry 273 6679-6688.

Northrop JP, Nguyen D, Piplani S, Olivan SE, Kwan ST, Go NF, Hart CP \& Schatz PJ 2000 Selection of estrogen receptor betaand thyroid hormone receptor beta-specific coactivator-mimetic peptides using recombinant peptide libraries. Molecular Endocrinology 14 605-622.

Paige LA, Christensen DJ, Gron H, Norris JD, Gottlin EB, Padilla KM, Chang C-Y, Ballas LM, Hamilton PT, McDonnell DP et al. 1999 Estrogen receptor (ER) modulators each induce distinct conformational changes in ER alpha and ER beta. PNAS 96 3999-4004.

Peale FV Jr, Ishibe Y, Klinge CM, Zain S, Hilf R \& Bambara RA 1989 Rapid purification of the estrogen receptor by sequence-specific DNA affinity chromatography. Biochemistry 28 $8671-8675$.

Ramsey TL \& Klinge CM 2001 Estrogen response element binding induces alterations in estrogen receptor $\alpha$ conformation as revealed by susceptibility to partial proteolysis. Fournal of Molecular Endocrinology 27 275-292.

Safe S 2001 Transcriptional activation of genes by 17 beta-estradiol through estrogen receptor-Spl interactions. Vitamins and Hormones 62 231-252.

Sathya G, Wenzhou L, Klinge CM, Anolik JH, Hilf R \& Bambara RA 1997 Effects of multiple estrogen responsive elements, their spacing and location on estrogen response of reporter genes. Molecular Endocrinology $111994-2003$.

Shang Y \& Brown M 2002 Molecular determinants for the tissue specificity of SERMs. Science 295 2465-2468.

Shibata H, Spencer E, Onate SA, Jenster G, Tsai SY, Tsai MJ \& O'Malley BW 1997 Role of co-activators and co-repressors in the mechanism of steroid/thyroid receptor action. Recent Progress in Hormone Research 52 141-164.

Smith CL, Nawaz Z \& O’Malley BW 1997 Coactivator and corepressor regulation of the agonist/antagonist activity of the mixed antiestrogen, 4-hydroxytamoxifen. Molecular Endocrinology 11 $657-666$. 
Sotiriou C, Neo SY, McShane LM, Korn EL, Long PM, Jazaeri A, Martiat P, Fox SB, Harris AL \& Liu ET 2003 Breast cancer classification and prognosis based on gene expression profiles from a population-based study. PNAS 100 10393-10398.

Struhl K 1998 Histone acetylation and transcriptional regulatory mechanisms. Genes and Development 12 599-606.

Teyssier C, Chen D \& Stallcup MR 2002 Requirement for multiple domains of the protein arginine methyltransferase CARM1 in its transcriptional coactivator function. Fournal of Biological Chemistry $27746066-46072$.

Tyulmenkov VT \& Klinge CM $2000 a$ Interaction of tetrahydrocrysene ketone with estrogen receptors $\alpha$ and $\beta$ indicates conformational differences in the receptor subtypes. Archives of Biochemistry and Biophysics 381 135-142.

Tyulmenkov VT \& Klinge CM $2000 b$ Selectivity of detection of estrogen receptors $\alpha$ and $\beta$ with cognate antibodies in electrophoretic mobility shift assay. Steroids 65 505-512.

Tyulmenkov VV \& Klinge CM 2001 $a$ Estrogen receptors alpha and beta exhibit different estradiol and estrogen response element binding in the presence of nonspecific DNA. Archives of Biochemistry and Biophysics 390 253-264.

Tyulmenkov VV \& Klinge CM $2001 b$ A mathematical approach to predict the affinity of estrogen receptors alpha and beta binding to DNA. Molecular and Cellular Endocrinology 182 109-119.

Tyulmenkov VT, Jernigan SC \& Klinge CM 2000 Comparison of transcriptional synergy of estrogen receptors alpha and beta from multiple tandem estrogen response elements. Molecular and Cellular Endocrinology 165 151-161.

Watanabe M, Yanagisawa J, Kitagawa H, Takeyama K, Ogawa S, Arao Y, Suzawa M, Kobayashi Y, Yano T, Yoshikawa H et al. 2001 A subfamily of RNA-binding DEAD-box proteins acts as an estrogen receptor alpha coactivator through the N-terminal activation domain (AF-1) with an RNA coactivator, SRA. EMBO fournal 20 1341-1352.

Weatherman RV \& Scanlan TS 2001 Unique protein determinants of the subtype-selective ligand responses of the estrogen receptors
(ERalpha and ERbeta) at AP-1 sites. Fournal of Biological Chemistry 276 3827-3832.

Webb P, Lopez GN, Uht RM \& Kushner PJ 1995 Tamoxifen activation of the estrogen receptor/AP-1 pathway. Molecular Endocrinology 9 443-456.

Webb P, Nguyen P \& Kushner PJ 2003 Differential SERM effects on corepressor binding dictate ERalpha activity in vivo. Fournal of Biological Chemistry 278 6912-6920.

Wong CW, Komm B \& Cheskis BJ 2001 Structure-function evaluation of ER alpha and beta interplay with SRC family coactivators. ER selective ligands. Biochemistry 40 6756-6765.

Wood JR, Greene GL \& Nardulli AM 1998 Estrogen response elements function as allosteric modulators of estrogen receptor conformation. Molecular and Cellular Biology 18 1927-1934.

Wood JR, Likhite VS, Loven MA \& Nardulli AM 2001 Allosteric modulation of estrogen receptor conformation by different estrogen response elements. Molecular Endocrinology 15 1114-1126.

Yi P, Driscoll MD, Huang J, Bhagat S, Hilf R, Bambara RA \& Muyan M 2002 The effects of estrogen-responsive element- and ligand-induced structural changes on the recruitment of cofactors and transcriptional responses by ERalpha and ERbeta. Molecular Endocrinology 16 674-693.

Zhang H, Thomsen JS, Johansson L, Gustafsson JA \& Treuter E 2000 DAX-1 functions as an LXXLL-containing corepressor for activated estrogen receptors. Fournal of Biological Chemistry $\mathbf{2 7 5}$ 39855-39859.

Zhang X, Jeyakumar M, Petukhov S \& Bagchi MK 1998 A nuclear receptor corepressor modulates transcriptional activity of antagonist-occupied steroid hormone receptor. Molecular Endocrinology 12 513-524.

\section{Received 24 February 2004 \\ Accepted 11 June 2004}

